\title{
Some features of the Holocene insect faunas of northeastern Siberia
}

\author{
Svetlana Kuzmina ${ }^{\mathrm{a}, \mathrm{b}, *}$, Andrei Sher ${ }^{\mathrm{c}}$ \\ ${ }^{a}$ Geography Department, Royal Holloway, University of London, Egham, Surrey TW20 OEX, UK \\ ${ }^{\mathrm{b}}$ Paleontological Institute, Russian Academy of Sciences, Profsoyuznaya 123, 117868 Moscow, Russia \\ ${ }^{\mathrm{c}}$ Severtsov Institute of Ecology and Evolution, Russian Academy of Sciences, 33 Leninsky Prospect, 119071 Moscow, Russia
}

Received 1 November 2004; accepted 10 April 2005

\begin{abstract}
The composition of fossil insect faunas from northeastern Siberia changed significantly during the Pleistocene-Holocene transition. The Late Pleistocene insect fauna reflects tundra-steppe environments, and was dominated by xerophilic species. This fauna persisted regionally until ca 12,000 yr BP. A radical transformation of the environment occurred between 12,000 and 10,000 yr BP, marked by the permafrost degradation and invasion of tall shrubs and later trees into the higher latitudes. The early Holocene insect assemblages are dominated by mesophilic tundra species, but also include small number of more thermophilic species, which are currently restricted to the taiga zone. Treedependent species, however, were virtually absent. This early Holocene fauna has no modern analogue. The faunal assemblages indicate that the early Holocene climate was more humid than that of the Late Pleistocene, and warmer than today. Post-glacial sea level rise was in progress at that time, but the shoreline was still much further north, and the New Siberian Islands were still a part of the mainland.

During the second-half of the Holocene, sea level continued to rise, and trees and tall shrubs retreated to the south. Regional ecosystems, including insect faunas, approached their modern compositions and boundaries.

(C) 2006 Elsevier Ltd. All rights reserved.
\end{abstract}

\section{Introduction}

Distinctive cryoxerophilic landscapes (tundra-steppe) dominated northeastern Siberia from the Taimyr Peninsula to Chukotka during the Pleistocene. The tundra-steppe was a grassland ecosystem with diverse mammalian grazers (the mammoth fauna). Herbivorous animals such as horse, bison and saiga antelope would not have been able to survive in the modern moist environments of arctic tundra or taiga. The insect fauna and flora of the Pleistocene tundra-steppe biome also had unusual combinations of species, combining those currently known only in the Arctic with more warm- and dry-adapted species, with modern ranges restricted to the steppe or forest zones. This suggests that the Pleistocene tundra-steppe biome has no complete modern analogues.

The vast plains of northeastern Siberia were never covered by glaciers, and retained their continental climate

\footnotetext{
*Corresponding author. Geography Department, Royal Holloway, University of London, Egham, Surrey TW20 0EX, UK.

E-mail address: Svetlana.Kuzmina@rhul.ac.uk (S. Kuzmina).
}

during the Pleistocene. Because of this, the tundra-steppe communities were able to survive climatic variations, including periods when the Siberian climate was relatively mild. As a consequence, the insect assemblages of northeastern Siberia, existing under various climatic regimes during the last million years or more, all included representatives of three major ecological groups - tundra, taiga and steppe-but in different quantitative proportions. This phenomenon was discovered by Kiselyov (1981), who called it "the continuity in faunal evolution." It is very important for the understanding of the regional history of insect faunas, especially when compared with Europe, with its much more dramatic changes in faunal composition through the glacial/interglacial cycles. Such a continuity explains the relatively stable Pleistocene species composition of beetle faunas in northeastern Siberia. We have corroborated this continuity in our recent research (Kuzmina, 2001; Sher et al., 2003).

The collapse of the tundra-steppe ecosystem occurred only about 10,000 yrs ago, at the Pleistocene-Holocene boundary. That event was irreversible, as it resulted in the extinction of several large grazing mammal species, such as 
mammoth and woolly rhinoceros. These animals were important components of the Pleistocene ecosystem. Thus, the transformation of the environment at the PleistoceneHolocene boundary was the greatest ecosystem restructuring during the whole history of the Quaternary. This transition had significant effects on the Siberian biota.

The climatic and environmental changes at the Pleistocene-Holocene boundary were very rapid. For example, the catastrophic shrinkage and fragmentation of the woolly mammoth range took only several hundred years, and in about 2000 yrs these animals completely disappeared from the Eurasian mainland (Sher, 1997). The reconstruction of these events requires, first, continuous sediment sections covering the interval from about 13,000 to at least $8000{ }^{14} \mathrm{C}$ yr BP. Unfortunately, such sections seem to be very rare in northeastern Siberia. This interval is absent in most natural sections, and even in some lake cores (due to sedimentation breaks) or only parts of it are represented. Second, the sections potentially covering the transition must be studied in detail, with high resolution sampling and good dating control. That is also very rare in our study region. Despite the important progress in multidisciplinary studies of this transition period in the recent years (e.g., CAPE Project Members, 2001; Pisaric et al., 2001; Anderson et al., 2002; Velichko et al., 2002), many details of the ecosystem transformation during this time remain unclear. The recently published database of radiocarbon dates and palynology of the Late Pleistocene and Holocene of northeastern Siberia (Anderson and Lozhkin, 2002) includes 25 sites east of the Verkhoyansk Mountains, potentially covering the specified age range. However, only four of them comply with all of the requirements discussed above (all of the sites represent lake cores, see comments below); all of the rest either have a gap in the transition record, or have had insufficient or controversial dating control for that period.

Fossil insects (mostly beetles) are known to be sensitive indicators of the past environment and climate (Coope, 1967; Kiselyov, 1981; Elias, 1994). Hence, the study of fossil insect assemblages has high potential for understanding ecosystem changes at the Pleistocene/Holocene boundary and the establishment of the modern landscape and fauna. In Europe, for example, high resolution records of beetle assemblages have provided extremely interesting evidence on the climatic and environmental changes during the Pleistocene termination and transition to the Holocene, later corroborated by other methods (Coope, 1970; Lowe and Walker, 1997). In northeastern Siberia insect assemblages also underwent very significant changes at the Pleistocene-Holocene transition, but the chronology of these events, in contrast to Europe, is still poorly known.

Systematic research on Late Cenozoic insects in northeastern Siberia began in the early 1970s and focussed mainly on the areas of the Kolyma Lowland and western Chukotka, where various Late Pliocene to Holocene fossil assemblages were studied (Kiselyov, 1981; Kuzmina, 1989). That pioneering research concentrated mostly on Pleisto- cene assemblages, and never focussed specifically on the Holocene. Moreover, the Holocene sections were usually sampled by Quaternary geologists, who obtained only small-sized samples; hence the number of insect fossils retrieved was low. Therefore, despite a large list of Holocene insect sites (such as Khroma River, Bylgnyr, Krest-Mayor, Sededema River, Bolshaya Chukochya River, Medvezhyi Islands, Duvanny Yar, Krestovka, Omolon River, Primorsky, Mil'kera, Ayon IslandFig. 1, sites 6-17), relatively little fossil material was available for study. Some of the Holocene sections were examined in greater detail (Kiselyov, 1980, 1995; Boyarskaya et al., 1983; Kuzmina, 1987, 1989; Kuzmina and Kolesnikov, 2000; Kuzmina and Bolshiyanov, 2002), but many others are represented by single samples (Kiselyov, 1981, 1995; Sher et al., 2006). Very few of the Holocene sites in northeastern Siberia that were studied by palynologists and ${ }^{14} \mathrm{C}$-dated, have been sampled for fossil insects (only five of about 75 in Anderson and Lozhkin, 2002).

Since 1998, several Quaternary sections in the Lena Delta area and on Bolshoy Lyakhovsky Island (New Siberian Archipelago) became the subjects of detailed multidisciplinary studies under the Russian-German program "Laptev Sea System 2000". This research program provided numerous radiocarbon dates. Our work in the Laptev Sea area during four field seasons (1998-2002) was concentrated mainly in three areas (Fig. 1): 1-the Bykovsky Peninsula $\left(71.8^{\circ} \mathrm{N}, 129.3^{\circ} \mathrm{E}\right) ; 2$-Kurungnakh Island in the south-central Lena Delta $\left(72.3^{\circ} \mathrm{N}, 126.3^{\circ} \mathrm{E}\right)$ with the adjacent small islands Samoylov (Site 2a) and Arga-Bilir-Aryta; and 3-on the southern coast of Bolshoy Lyakhovsky Island at the Zimovye River mouth $\left(73.3^{\circ} \mathrm{N}\right.$, $141.3^{\circ} \mathrm{E}$ ). Unfortunately, we were not able to study any of these sites with the degree of detail and resolution discussed above. However, the results obtained are interesting, since Holocene beetle faunas from such high latitudes have before never been studied in Siberia, and they may shed some light on the issues outlined above. In particular, they show the very peculiar character of early Holocene insect assemblages in this region. They were dramatically different from the preceding Late Pleistocene faunas of the tundra-steppe type, but most probably retained some steppe species very characteristic of those faunas. On the other hand, they do not match any modern ecosystem assemblages.

This paper reports the most recent data on Holocene insect assemblages from the Laptev Sea area and attempts to summarize the existing evidence on the development of the insect fauna in northeastern Siberia in comparison with the proxy evidence from other, mostly paleobotanical sources.

\section{Methods}

Insects have a number of merits as a tool for the environmental reconstruction. They are good environmental indicators and provide more detailed information about the past than is available from pollen analysis, primarily 


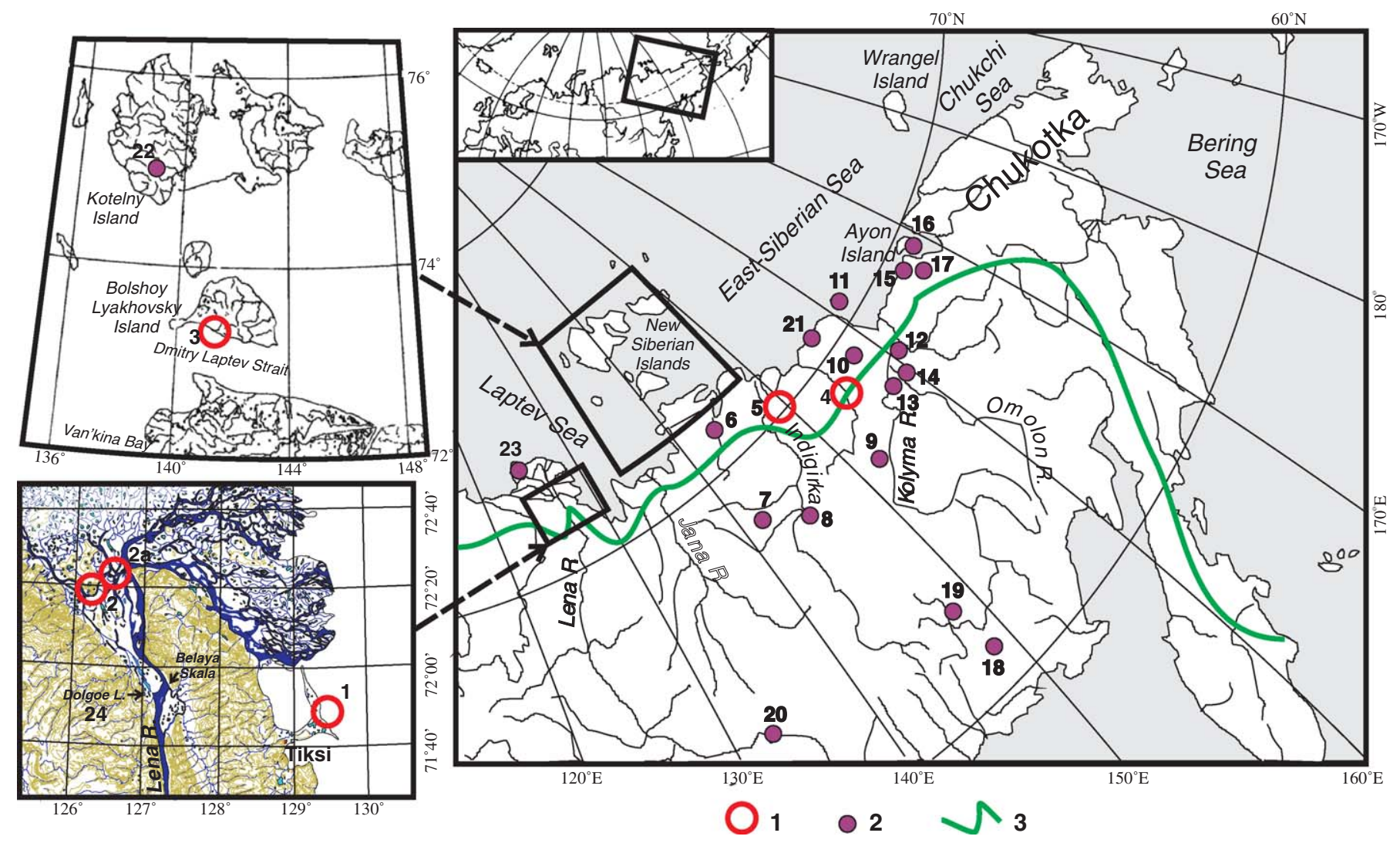

Fig. 1. Map of Holocene sites and the position of the modern treeline.

Legend: 1 - the insect fossil sites described in detail in this paper; 2 - other sites mentioned in the text, including important Holocene sections with no fossil beetle record; 3 - modern treeline.

Fossil site key: 1-Bykovsky Peninsula (Mamontovy Khayata, Mamontovy Bysagasa); 2-Lena Delta, Kurungnakh Island, 2a—Arga-Bilir-Aryta and Samoylov Islands; 3-Bolshoy Lyakhovsky Island; 4-Alazeya River, 5-Keremesit River; 6-Khroma River; 7-Bylgnyr; 8-Krest-Mayor; 9Sededema River; 10 - Bolshaya Chukochya River; 11-Medvezhyi Islands; 12-Duvanny Yar; 13-Krestovka; 14 Omolon; 15-Primorsky; 16 - Ayon Island; 17-Mil'kera; 18-Ust'-Omchug; 19-Dima Baby Mammoth Site; 20-Aldan River; Other Holocene sites with no beetle record: 21—Bolshaya Kuropatochya River; 22-Kotelny Island, Balyktakh River; 23-Nykolay Lake; 24—Dolgoe Ozero Lake.

because most insect remains can be identified to the species level. Insect fossils are usually abundant both in the Pleistocene and Holocene deposits of the Arctic regions (Kiselyov, 1981; Kuzmina, 2001).

Our field methods of collecting insect fossils have been explained in previous publications (Kuzmina et al., 1999; Sher et al., 2002a,b). In order to use our quantitative approach to faunal analysis of insect assemblages (see below), we needed to maximize the number of specimens from each sample. The common practice of taking bulk samples in the field for further processing in the laboratory is not usually satisfactory for this purpose, as such samples very rarely contain sufficient numbers of insect fossils. Accordingly, we screened large volumes of sediment in the field, usually $30-40 \mathrm{~kg}$, but quite often up to $100-150 \mathrm{~kg}$. We used large wooden-framed boxes with $0.5 \mathrm{~mm}$ mesh screens in the bottom. The application of a smaller mesh for such large volumes of sediment is not practical. Our experiments with raw and sieved samples showed that very few identifiable beetle fossils are smaller than $0.5 \mathrm{~mm}$, and careful and gentle screening keeps most of them in the residue, because of their irregular shape.
Taking such large volumes from a thin layer of sediment is especially difficult in permafrost sections. Therefore, the layers examined are usually up to $15-20 \mathrm{~cm}$ thick. Unfortunately, that lowers the chronological resolution of the method, as one sample may contain insect remains accumulated for several hundred years, and the result will therefore be generalized. Thus, some rapid changes in the environment can be misinterpreted or missed.

The ecological analysis of fossil assemblage structure and the quantitative evaluation of this structure are the main principles of our interpretation of the fossil insect data. Such an approach is more common in northeastern Siberia with its relatively low taxonomic diversity of Quaternary insect species (Kiselyov, 1981; Kuzmina, 1989, 2001), than, for example, in Europe, where traditionally, more emphasis was placed on individual species. Under this approach, we have to classify all the fossil insect species into a certain number of ecological categories (groups). For each sample, the number of fossils (minimum number of individuals, MNI) of each species is taken into account, then they are summarized by ecological categories, and the final characteristic of the assemblage 
consists of the percentage of these categories. This approach is based on the assumption that the percentage of an ecological group can be used as a relative measure of the corresponding habitat availability while comparing the fossil assemblages of different age. The problem is that, for the purpose of the quantitative estimation, the number of ecological groups should not be very large, and each species should be assigned only to one ecological group. The latter is not always an easy task, as some species can occupy different habitats in different latitudinal zones, many species now have relict distributions, and so on. Thus, the accepted ecological definition of each particular species, in the view of some other experts, may not always correspond to the name of the group to which it is assigned in our classification, and correspondingly to the index (EcoCode), given to it by us, which is usually an abbreviation of the group name. The main idea behind that classification is to follow the main environmental signal, which particular species may reflect in the present Arctic and Subarctic environment. This means that our classification is not universal, but regional, and the names of the ecological groups are largely conventional. In general, this approach provides an easy and convenient way to trace the dynamics of the insect assemblages through time, especially when dealing with geological sections, sampled for insect fossils with more-or-less short intervals between the samples.

In this paper, we use the same ecological groups that we applied for the Late Pleistocene assemblages in a recent publication (Sher et al., 2005). We described the groups in detail there, but we briefly repeat their characteristic below, with their associated EcoCodes. The ecological assignment of each particular species is given in the table in the on-line version of this article.

The first four groups are xerophilic insects, uncommon or absent in the modern tundra zone:

(1) "Steppe" (st) - insects of thermophilic steppe (mostly weevils Stephanocleonus spp.).

(2) "Meadow-steppe" (ms) - insects of meadow-steppe and steppe-like habitats in the tundra zone (e.g. weevils Coniocleonus spp., some leaf beetles, and the soft-winged flower beetle Troglocollops arcticus). These show close affinities to their true steppedwelling relatives.

(3) Insects of hemicryophytic steppe ${ }^{1}$ (ss) - only one species of pill beetle with very peculiar ecology (Morychus viridis) (Berman, 1992).

\footnotetext{
${ }^{1}$ Various regions with continental climate in northeastern Siberia are known to retain areas of relict steppic vegetation within the taiga or even tundra zones, sometimes quite high in the Arctic. The study of relict steppe communities in the North allowed Yurtsev (1981) to classify them by their floristic composition and according to the level of heat supply. These range from cryophytic (the coldest relict steppe) to thermophytic (the warmest). The hemicryophytic steppe is an intermediate category of cold relict steppe, dominated by several species of xerophilic sedge, and is widespread in northeastern Siberia. It is of special interest of biologists (Berman et al., 2001) because it is the modern habitat of one of the most common and abundant Pleistocene beetle species-M. viridis (Byrrhidae).
}

(4) Xerophilic insects of different habitats (ks) - dung beetles Aphodius spp., the ground beetle Notiophilus aquaticus.

The next three groups are common in various modern tundra habitats:

(5) Insects of dry tundra habitats (dt), including various ground beetles, such as Curtonotus alpinus, Pterostichus sublaevis, the weevils Sitona borealis and Hypera ornata, and others.

(6) Insects from typical and arctic tundra (tt), including the willow weevil Isochnus arcticus and several species of the arctic leaf beetle genus Chrysolina.

(7) Insects of mesic tundra habitats (mt), including various ground beetles, such as Pterostichus (Cryobius) spp., Pterostichus costatus, the rove beetle Tachinus arcticus and others.

The following groups include species that may indicate the presence of trees and more-or-less tall shrubs in various ways. They are common in foresttundra today. Some occur in the southern (shrub) tundra, but almost none enters the typical tundra subzone:

(8) Insects associated mostly with shrubs, except dwarf shrubs of typical and arctic tundra (sh) - including the weevils Lepyrus spp., and some other weevils and leaf beetles.

(9) Insects living in meadows, mostly in the forest zone (me), although some species of this group can occur on tundra meadows, including the leaf beetle, Phaedon concinnus, and others.

(10) Tree-associated insects and insects restricted to the taiga zone (ta), including ants, the weevils Pissodes spp., and others.

The insects related to water and wet habitats are usually distributed in several zones:

(11) Riparian species (na), including the ground beetles Elaphrus spp. and Nebria spp., most of the species of Bembidion that occur in tundra habitats, bugs of the family Saldidae and many others.

(12) Aquatic insects (aq), including predaceous diving beetles, water scavenger beetles, and water bugs.

(13) Insects of various habitats (such as plant litter, or fungi) and undetermined insects (oth).

It should be taken into account that the level of knowledge of modern beetles in Siberia is much lower than in Europe. A detailed regional check-list for the whole order is not available. There are some general check-lists (e.g., on the web site of the Zoological Institute of St. Petersburg), but they are not sufficiently full and detailed. There are published check-lists for certain families (e.g., Carabidae: Kryzhanovskij et al., 1995), and we have used them, but most of the evidence on beetle species taxonomy, distribution and ecology has been collated from data in many dozens of publications (both taxonomic and faunistic). Currently, we are preparing a database on insect 
species known as fossils in northeastern Siberia (Sher et al., 2006).

Concerning Holocene stratigraphy, many Russian papers still apply the classic European scheme of the BlyttSernander Holocene climatostratigraphic units. It has been shown, however, that the Holocene climate changes in eastern Siberia did not coincide with the European sequence (Kaplina and Lozhkin, 1979). One of the main differences is that in Europe the "Holocene Climatic Optimum" (the temperature maximum coinciding with high humidity, allowing the northern advance of temperate forest) occurred in the Atlantic period, i.e. after $8 \mathrm{kyr}$, while a more-or-less similar climatic event in northeastern Siberia (the tree advance to the Arctic and the extensive peat accumulation, also caused by the simultaneous increase in temperature and humidity) took place before $8 \mathrm{kyr}$. Thus, the Blytt-Sernander climatostratigraphic units cannot be used in our region in their original meaning. For this reason, like the authors of numerous publications in Eurasia and North America, we prefer to use informal subdivisions of the Holocene, more neutral and corresponding more closely to our regional evidence. These are the early Holocene $(10,000-7000$ yr BP), the middle Holocene (7000-4000 yr BP) and the late Holocene (4000-0 yr BP). However, because of wide acceptance of the BlyttSernander scale in the literature, we provide a comparative chart, in which we plot our data against that scale to facilitate possible correlations. For this purpose, we use the Russian modification of the scale (Khotinskiy, 1977, 1984), recently applied by Anderson and Lozhkin (2002) in their review of the pollen evidence for northeastern Siberia.

All radiocarbon dates mentioned in this paper are listed in Table 1, along with the full information on samples and dates (laboratory code, location, material dated, raw date, error and calibrated age range). In the text, however, we prefer to cite uncalibrated radiocarbon ages, for the following reason. The trend of using calendar ages is not so strong in Russia, as it is in the West, even for the Holocene and the latest Pleistocene. Most published works that we cite in our paper use only uncalibrated radiocarbon ages. The most recent example is the Russian-American database on palynology and radiocarbon of the Late Pleistocene and Holocene of Siberia, in which no ages are calibrated (Anderson and Lozhkin, 2002). Keeping the single uncalibrated system throughout the text helps to avoid confusion, and the addition of Table 1 allows the interested reader to compare those data with the calendar scale (e.g., to correlate with events in other parts of the world).

\section{The study areas}

\subsection{Localities in the Laptev Sea area, modern climate, vegetation and insect fauna}

All three areas of our research are in the Siberian Arctic, from $72^{\circ} \mathrm{N}$ to $73^{\circ} \mathrm{N}$, at or near the Arctic Ocean coast. The arctic climate in this region is strongly affected by the sea. Summer is colder than in the inland regions (mean July temperature varies from 2.5 to $9.0^{\circ} \mathrm{C}$ ), while winter is relatively mild $\left(-30\right.$ to $\left.-34^{\circ} \mathrm{C}\right)$; mean annual temperature is -13 to $-14{ }^{\circ} \mathrm{C}$ (Reference Book on Climate of the USSR, 1966-1968). Continuous permafrost is up to $600 \mathrm{~m}$ thick. Although all three study areas are currently in the tundra zone, their modern environments are somewhat different, as explained below.

Bykovsky Peninsula (Fig. 1, Site 1) lies southeast of the huge delta of the Lena River, near the town of Tiksi, and is almost completely surrounded by the sea. Because of the coastal position of the site, mean July air temperature is not higher than $7{ }^{\circ} \mathrm{C}$ (Tiksi), or even as low as $4.3^{\circ} \mathrm{C}$ (Muostakh Island $30 \mathrm{~km} \mathrm{SE}$ of the MKh cliff). Our work was concentrated at the coastal cliffs in the south-eastern part of the peninsula, facing the Laptev Sea. The Mamontovy Khayata (MKh) cliff $\left(71.79^{\circ} \mathrm{N}, 129.40^{\circ} \mathrm{E}\right)$ is 40-m high and is composed of Late Pleistocene sediments, capped by the thin layer of Holocene sediments (Kuzmina et al., 2002; Schirrmeister et al., 2002a; Sher et al., 2005). Other Holocene sediments were studied in the abraded cliff of the terrace-like surface, up to $10 \mathrm{~m}$ high, $2.5 \mathrm{~km} \mathrm{NW}$ of Mkh. This is called the Mamontovy Bysagasa (MB) exposure $\left(71.81^{\circ} \mathrm{N}, 129.35^{\circ} \mathrm{E}\right)$. The modern vegetation in this part of the Bykovsky Peninsula is mainly moss-grass tundra, with prostrate willows (e.g., Salix pulchra, S. glauca) and some dwarf birch (Betula exilis). There are also many wet sites with various mosses. This vegetation is characteristic of the typical tundra subzone. The soil is peaty or silty, sandy soil patches are rare, and stony soils are absent. The modern insect fauna consists mostly of mesophilic and hydrophilic species; xerophilic insects are very rare, and species diversity is low.

On Kurungnakh Island (Fig. 1, Site 2), the studied sections are on the right bank of the Olenyok Channel near its separation from the Lena, in the south-central part of the Delta. The Buor-Khaya Bluff (BKh) is $35 \mathrm{~m}$ high and composed of Pleistocene deposits of various ages (Kuzmina et al., 2003; Schirrmeister et al., 2003). We studied the Holocene sediments in two localities in the upper part of the bluff and in lower river terrace. Although this site is slightly further north $\left(72.3^{\circ} \mathrm{N}, 126.28^{\circ} \mathrm{E}\right)$ of those on the Bykovsky Peninsula, its summer climate is a little warmer (mean July temperature is $8.9^{\circ} \mathrm{C}$ ). That is explained by the more distant position of the $\mathrm{BKh}$ site from the sea, combined with the warming effect of the Lena River. Thus, the BKh site is still within the limit of the southern (shrub) subzone of the tundra zone. The elevated surface of Kurungnakh Island has extensive dwarf birch cover, while single low bushes of shrub alder (Duschekia fruticosa) occur on the lower terraces. The soil is mostly sandy, as on other Lena Delta islands, and there are many sites with xerophytic herb vegetation. The insect fauna of Kurungnakh Island, as on the nearby Samoylov Island (Kuzmina, 2003), consists of common tundra species, but the diversity is higher than on the Bykovsky Peninsula, and it includes 


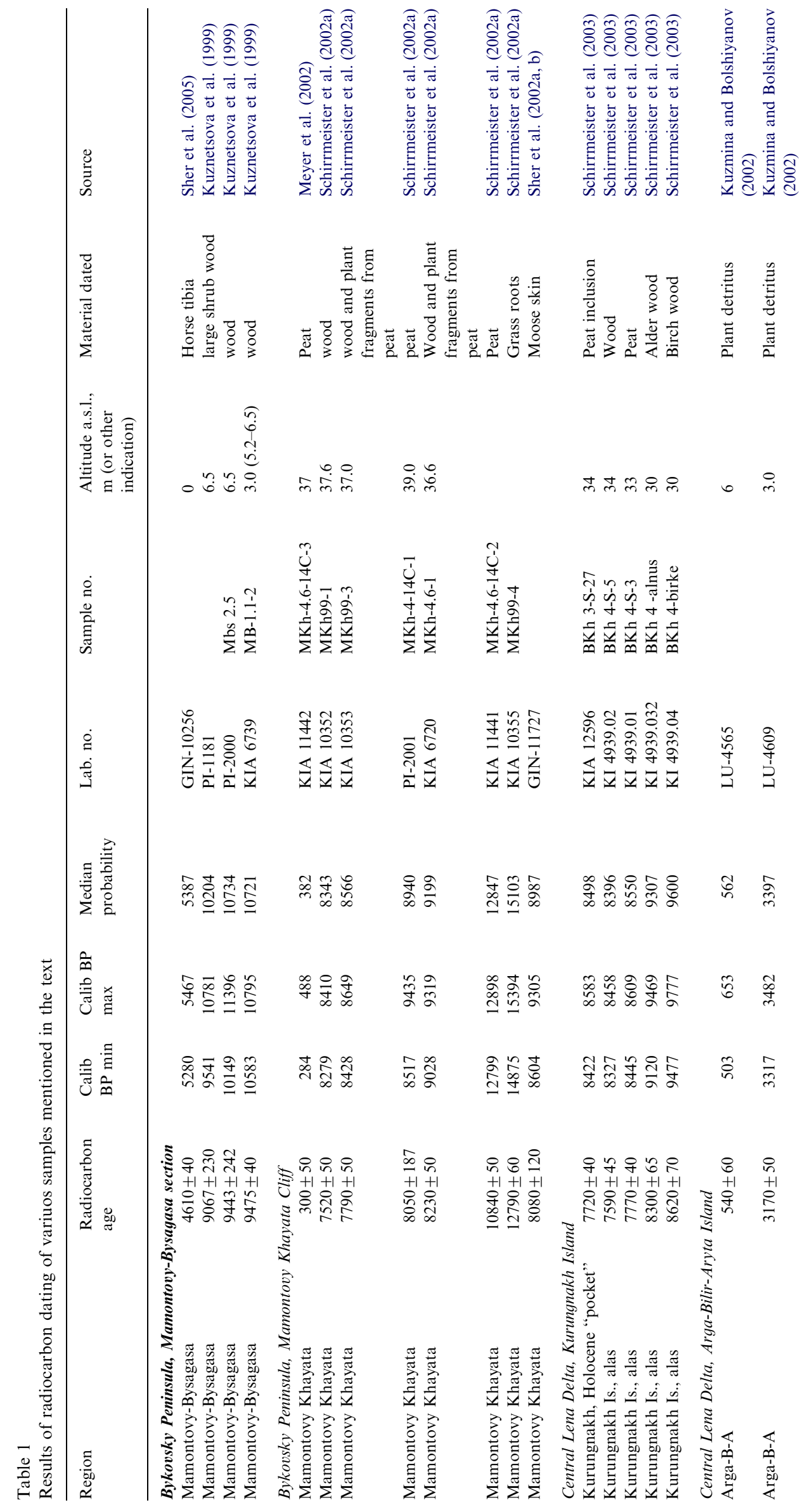




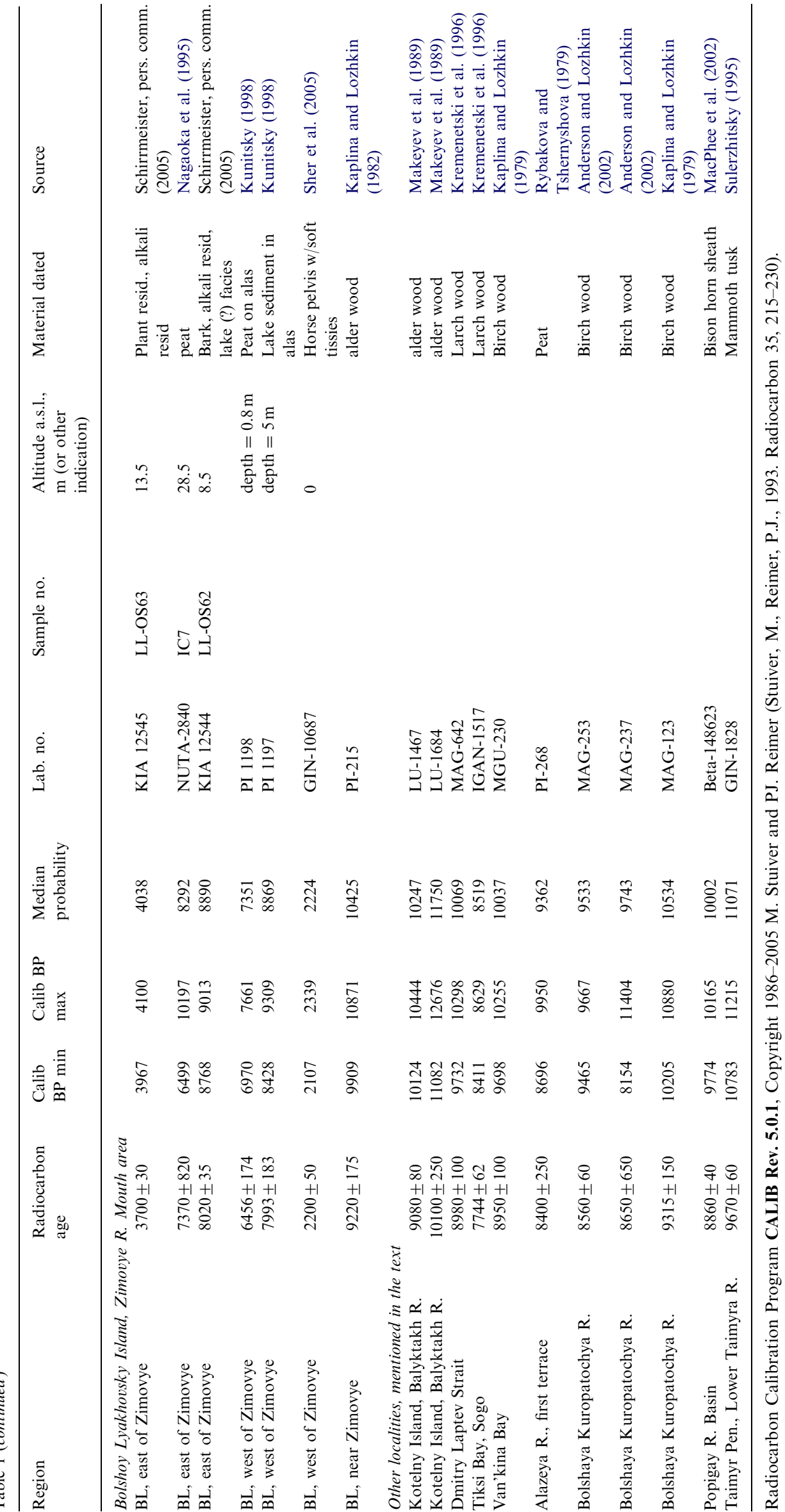


many xerophilic tundra species. Besides that, the modern fauna of these tundra areas includes some species that are common in taiga zone, such as the riparian ground beetle Elaphrus riparius, and the ant Leptothorax acervorum, ${ }^{2}$ which were found on Samoylov Island. Additionally, some forest insects are transported with Lena River driftwood to the Lena Delta and Bykovsky Peninsula. These include at least three xylophagous species, such as the long-horn beetles Monochamus sutor F. and Asemum striatum (L.), the metallic wood-boring beetle Melanophila acuminata (De Geer), and the carpenter ant Camponotus herculeanus that nests in wood. On warm sunny days at the end of July, one of us (SK) observed a mass flight of Monochamus sutor and Melanophila acuminata. At that time these beetles exceeded the primary tundra inhabitants in numbers, at least in the areas of driftwood accumulation. Along the Lena valley, the northern limit of larch (Larix dahurica) advances almost $60 \mathrm{~km}$ north of its main limit, up to the Tit-Ary Island $\left(72^{\circ} \mathrm{N}\right.$, see Fig. 1). In historical times, healthy, large larch trees still grew on that river island; they were cut down by exiled immigrants in the 1940s. Today there are only small larch trees on the island and on the opposite right bank of the Lena (no more than $10-15 \mathrm{~cm}$ in diameter). However, these are in good condition, with only a few weakened and dead trees, on which tree-associated insects usually settle. During a short visit to the Tit-Ary Island in early August of 2002, SK was unable to collect any true taiga insects. The modern catch included common tundra beetles, with some more thermophilic species, such as the ground beetle Carabus odoratus Motsch. (Kuzmina, 2003).

The third area (Fig. 1, Site 3) is the southern coast of Bolshoy Lyakhovsky Island, where continuous sea cliffs face the Dmitry Laptev Strait. The cliffs east and west of the Zimovye River mouth $\left(73.32^{\circ} \mathrm{N}, 141.37^{\circ} \mathrm{E}\right)$, up to $35 \mathrm{~m}$ high, expose a complicated sequence of the Early to Late Pleistocene sediments (Andreev et al., 2004a). Holocene deposits are represented in sections of thermokarst depressions (alasses), inserted into the Pleistocene sequence, in smaller insertions ("pockets") on the top of that sequence, and in the low terraces of the Zimovye River. This part of Bolshoy Lyakhovsky Island is mostly covered with grassy tundra vegetation, with stunted prostrate willows; the sites with open ground are rather abundant, while boggy terrain is rare because of the very shallow active layer. The studied sections are near the boundary between typical and arctic tundra subzones. The modern insect fauna has a low diversity and xerophilic species are virtually absent, but insect numbers are high. Species occurring in vast numbers include the ground beetle Pterostichus (Cryobius) ventricosus, the rove beetle Tachinus arcticus, and a few species of

\footnotetext{
${ }^{2}$ The list of Latin names of insect species from the described Holocene sites is given by families in the table in the on-line version of this article, including the species authors. The modern species, not included in the online table, are cited with the author names at their first occurrence in the text. There is no general and relatively full checklist of Siberian beetles (see comments on this point in "Methods").
}

arctic leaf beetles. Many individuals with frost-affected, irregular exoskeletons are found there.

\subsection{Holocene geology of the studied sites}

The most remarkable Late Pleistocene unit in northeastern Siberia, including all three of the study areas, is the so-called "Ice Complex"-mostly a silty formation, saturated with ice and including large syngenetic ice wedges. It has recently been studied in greatest detail from a site on the Bykovsky Peninsula (Fig. 1, site 1) (Schirrmeister et al., 2002a, b; Sher et al., 2005). Accumulation of the Ice Complex sediments was continuous until about $12,000 \mathrm{yr}$ BP. Then it ceased, and the rapid thermo-erosional destruction of the whole body of the Ice Complex (up to $40 \mathrm{~m}$ thick) began. This resulted in the formation of numerous alasses - thermokarst depressions, or kettles, which originally included water bodies (lakes). The process of lake thermokarst was very rapid (Tumskoy, 2002), and the lifetime of many of these lakes was short. By the early Holocene many of them had drained, and only some smaller residual lakes remained within large alasses. The dried lake beds and the drained alasses were densely vegetated, and almost all of them developed thick peat deposits during the Holocene.

Most alasses hosted creeks of larger or smaller size. Some of those creeks appeared as early in the alass history as the early Holocene and played a significant role both in the drainage of lakes, and in the Holocene sedimentation inside the alass kettle. The fluvial sediments in such alass sections, often of sandy composition, intercalate with the layers enriched with peat, wood and other plant remains. The Holocene sections of this kind are usually called "alass terraces" in Russian publications.

Holocene sediments of a different kind are found on the top of the partially eroded Yedoma (Ice Complex) surface. They form relatively small but regular insertions ("pockets") between the wide Pleistocene ice wedges. These insertions are $2-5 \mathrm{~m}$ in width and up to $2-3 \mathrm{~m}$ deep. They consist of very icy silts, in which the peat inclusions, looking like peat tussocks, are usually arranged in horizontal layers. Radiocarbon dates indicate their early Holocene age (see below). These small pockets are a very common phenomenon in all the study areas, and definitely reflect the climatically caused thermo-denudation of Ice Complex in the early Holocene, but the particular mechanism of their formation remains unclear (Sher et al., 2002a, b).

The flood-plains and the lowest river terraces of large and small rivers have also been formed in the Holocene. They are from 3-10 $\mathrm{m}$ high above the river, and are cut into the Yedoma (Ice Complex) surface and quite often into alass surfaces. In the Lena Delta area the fluvial sediments of these terraces date from the late Holocene. These sediments can include allochthonous macrofossils, both transported from a long-distance (in the case of the Lena 
River) and redeposited from the near-by Pleistocene exposures.

Finally, a relatively thin, but ubiquitous sheet of Holocene sediments of thermo-illuvial and slope origin covers the Yedoma surface. These sediments can accumulate in large volumes in erosional ravines and on the foothills. Our experience shows that they include large amounts of Pleistocene organic detritus, with a mixture of Holocene sediments. The dating and analyses of these deposits has yielded controversial results (Schirrmeister et al., 2002a, b). Accordingly, these sediments have been excluded from our discussion.

Particular sections of the main types of Holocene deposits in the Laptev Sea area (of typical alasses, alass terraces, top-Yedoma "pockets" and low fluvial terraces) are considered below in more detail.

\subsubsection{Alass sections}

A typical alass section consists of four main units. Starting at the bottom, the first of these is the Taberal Unit. Taberal units are composed of former Ice Complex sediments, thawed under the lake and compressed up to $80 \%$ of their original volume, but remaining in place, i.e. without redeposition or inclusion of younger material. These units usually contain Pleistocene fossils (such as mammal bones, insects, etc.) and yield Late Pleistocene ${ }^{14} \mathrm{C}$ dates. Next in this sequence is the Lacustrine Unit-the sediments of former lakes. Quite commonly, the boundary between the taberal and lacustrine units is marked by ice wedge pseudomorphs (casts), intruding into the upper part of the taberal sediments. These relatively small casts (up to $1-1.5 \mathrm{~m}$ wide) often include wood fragments (tree birch, alder, larch) or peat blocks; these organic materials provide early Holocene ${ }^{14} \mathrm{C}$ dates: $8760-6300 \mathrm{yr}$ BP (Kaplina and Lozhkin, 1979). Most lakes were originally formed in rather deep kettles surrounded by hills $20-30 \mathrm{~m}$ high, which were built by the Ice Complex. Since the products of Ice Complex destruction drained down into the lake, lacustrine sediments may potentially include redeposited Pleistocene fossils (pollen, insects), but they also include contemporaneous (Holocene) micro- and macrofossils (pollen, plant and insect remains, fresh-water shells and fish bones, but almost no mammal bones). Above this is the Peat Unitusually a thick autochthonous peat layer; in most cases the lower part of this peat yielded radiocarbon dates from 8900 to $7100{ }^{14} \mathrm{C}$ yr BP (Kaplina and Lozhkin, 1979). The sequence is capped by the Cover Unit, which varies in accordance with the individual alass life history - it may include a layer of late Holocene peat, as in most typical alasses, or may be a fluvial deposit (sands), if the alass became a creek channel.

We have studied an alass section LL-17 on Bolshoy Lyakhovsky Island, $1700 \mathrm{~m}$ east of the Zimovye River mouth (Fig. 1, Site 3). The sea-facing cliff is about $14 \mathrm{~m}$ high; its lower part is composed of older Pleistocene deposits. The alass section proper (Fig. 2) starts at an elevation of about $7 \mathrm{~m}$ a.s.l. (above sea level) with taberal sediments overlain by silts that include abundant branches and roots of shrub alder (identified by SK). According to V. Kunitsky (pers. comm.), this is probably a lacustrine unit. The wood bark from here (elevation $8.5 \mathrm{~m}$ a.s.1.) was AMS-dated at $8020 \pm 35$ yr BP (KIA 12544) ${ }^{3}$ (L. Schirrmeister, pers. comm. 2005). We have screened quite a rich insect sample from this locality (LL-17-B20). The lacustrine unit is overlain by a silt with peat lenses; an almost $2-m$ thick peat horizon tops the section. The insect sample, LL-17-B21, was taken from the peaty silt, immediately underlying the top peat. The radicarbon age of peat from the same elevation ( $13.5 \mathrm{~m}$ a.s.1.) is $3700 \pm 30 \mathrm{yr}$ BP (KIA 12545) (L. Schirrmeister, pers. comm. 2005).

The dating of the same alass in the section L21, $450 \mathrm{~m}$ further east, confirms the age of the lower alas unit (lacustrine?), but extends its range to ca $9000-7700 \mathrm{yr}$ BP (Grosse et al., 2002). The detailed studies of another alass section about $15 \mathrm{~m}$ high, $3.1-3.3 \mathrm{~km}$ west of the mouth of the Zimovye River, showed a similar age for the lacustrine unit: $7993 \pm 183$ yr BP, PI 1197 (Kunitsky, 1998). Another conventional date comes from the peat layer $4 \mathrm{~m}$ higher in the same section: $6456 \pm 174 \mathrm{yr}$ BP, PI 1198 (Kunitsky, 1998). Unfortunately, no insect samples have been obtained from these alasses.

On Kurungnakh Island (Fig. 1, Site 2), we have studied the alass section that is positioned on the high Yedoma surface. Here, a relatively small thermokarst lake has only slightly melted the underlying Late Pleistocene sediments. For this reason the bottom of the alass section is positioned here about $30 \mathrm{~m}$ above the river, and the whole thickness of alass deposits is a little more than $5 \mathrm{~m}$ (Fig. 3). They are represented by an intercalation of silt and peat layers and are very rich with woody plant remains, especially in the lower part. Wood samples of tree birch (Betula sp.) and shrub alder, taken at the elevation of $30 \mathrm{~m}$, produced conventional ${ }^{14} \mathrm{C}$ ages of $8620 \pm 70 \mathrm{yr}$ BP (KI 4939.04) and $8300 \pm 65$ yr BP (KI 4939.032), respectively (Schirrmeister et al., 2003). The insect sample BKh-B4 was screened from the same layer. The upper part of the sequence yielded the following dates: $7770 \pm 40 \mathrm{yr}$ BP (KI 4939.01) on peat at $33 \mathrm{~m}$, and $7590 \pm 45 \mathrm{yr}$ BP (KI 4939.02) on wood at $34 \mathrm{~m}$ (Schirrmeister et al., 2003).

\footnotetext{
${ }^{3}$ All radiocarbon dates in the text of this paper are non-calibrated, as well as all age estimates. Full information on the dates, including their calibrated calendar ranges, is given in Table 1. See also comments on calibration at the end of "Methods". The abbreviations for the radiocarbon laboratories are the following: KIA—Leibnitz Labor, Kiel, Germany (AMS); KI - the same lab, conventional dates; NUTATandetron AMS Laboratory, Nagoya University, Nagoya, Japan;BetaBeta Analytic, Maiami, Florida, USA (AMS); GIN—Geological Institute RAS, Moscow, Russia; IGAN-Institute of Geography, RAS, Moscow, Russia; LU—Geographical Research Institute, St.-Petersburg State University, Russia; MAG-North-Eastern Interdisciplinary Scientific Research Institute, Magadan, Russia; MGU—Moscow State University; PI-Permafrost Institute, Yakutsk, Russia (all Russian labs are conventional).
} 

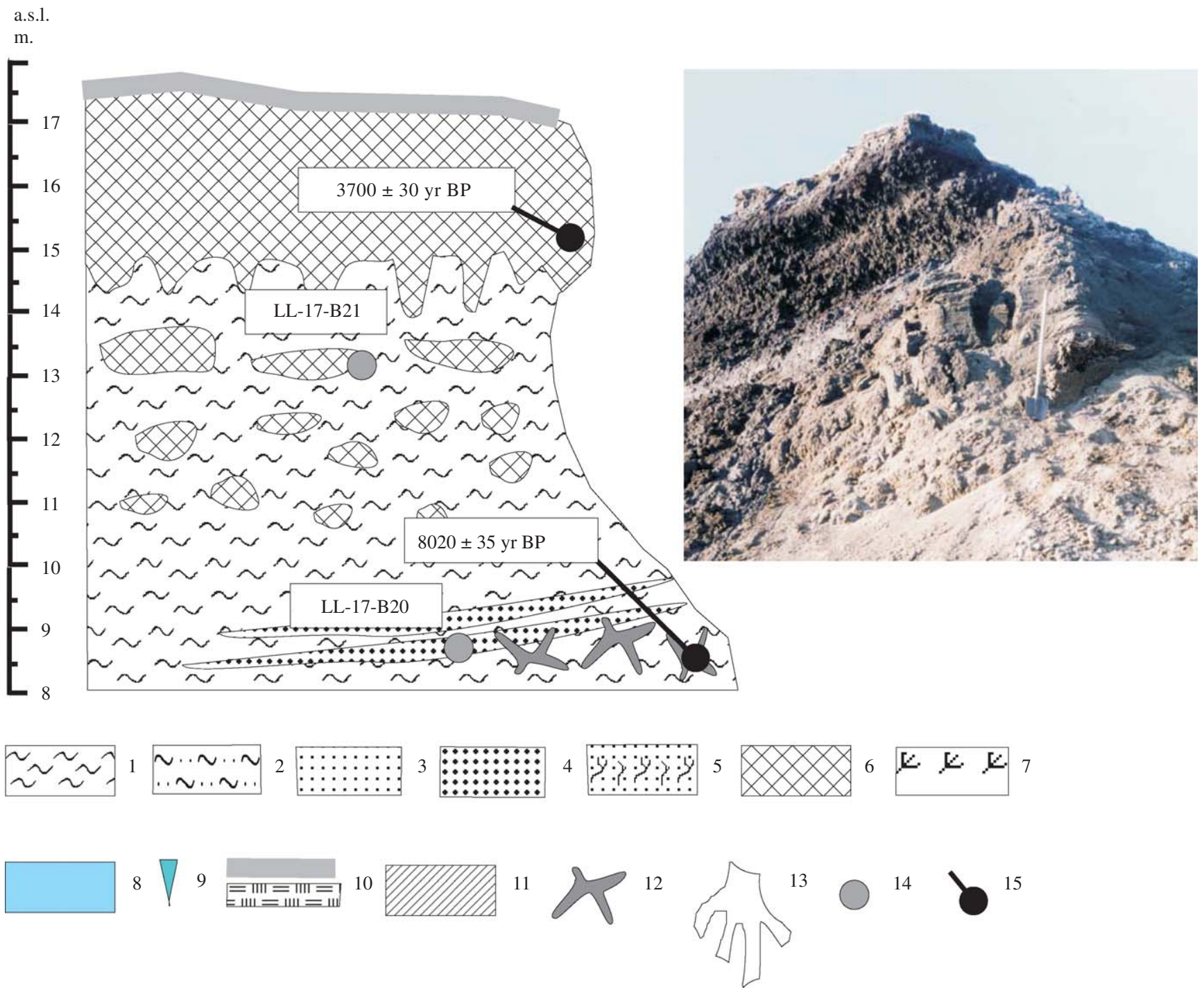

Fig. 2. Holocene alass section near the Zimovye River mouth on Bolshoy Lyakhovsky Island.

Legend for Figs. 2-9: 1-silt, 2 - sandy silt, 3-sand, 4- coarse-grained sand and gravel, 5- sand with grass remaines, 6-peat, 7-plant detritus, 8Pleistocene ice wedge, 9-Holocene ice wedge, 10 - modern soil, 11 - covered surface, 12 - shrub twigs and roots, 13-tree stumps, 14-insect samples, $15-\mathrm{C}^{14}$ samples.

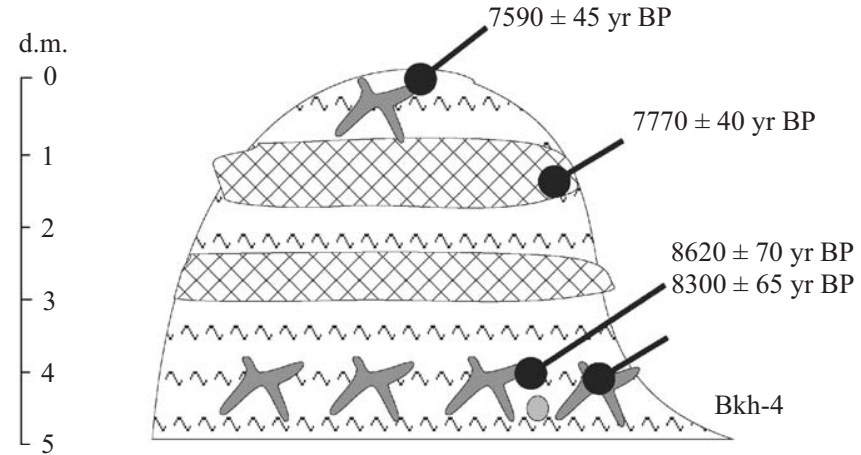

Fig. 3. Byor-Khaya section, Kurungnakh Island, Lena Delta, alass deposits on the top of Ice Complex.

\subsubsection{Alass terrace section}

The MB section is a seashore cliff about seven meters high (Fig. 4). The section consists of two units. The lower unit (visible thickness $5 \mathrm{~m}$ ) is composed of compact grey silt with lenses of fine-grained sand and plant detritus. The upper unit, up to $3.5 \mathrm{~m}$ thick, consists mostly of sand, rich with various plant remains - parts of large shrubs, sometimes with bark (shrub alder and birch), and tree logs and stumps of larch, some of the latter in growth position. This unit also contains shells of freshwater bivalves and gastropods. Thick branches and roots yielded conventional ${ }^{14} \mathrm{C}$ ages of $9067 \pm 230 \mathrm{yr}$ BP (PI-1181), $9443 \pm 242 \mathrm{yr}$ BP (PI-2000) and an AMS ${ }^{14} \mathrm{C}$ age of $9475 \pm 40 \mathrm{yr}$ BP (KIA 6739) (Kuznetsova et al., 1999). The lower unit is taberal in 


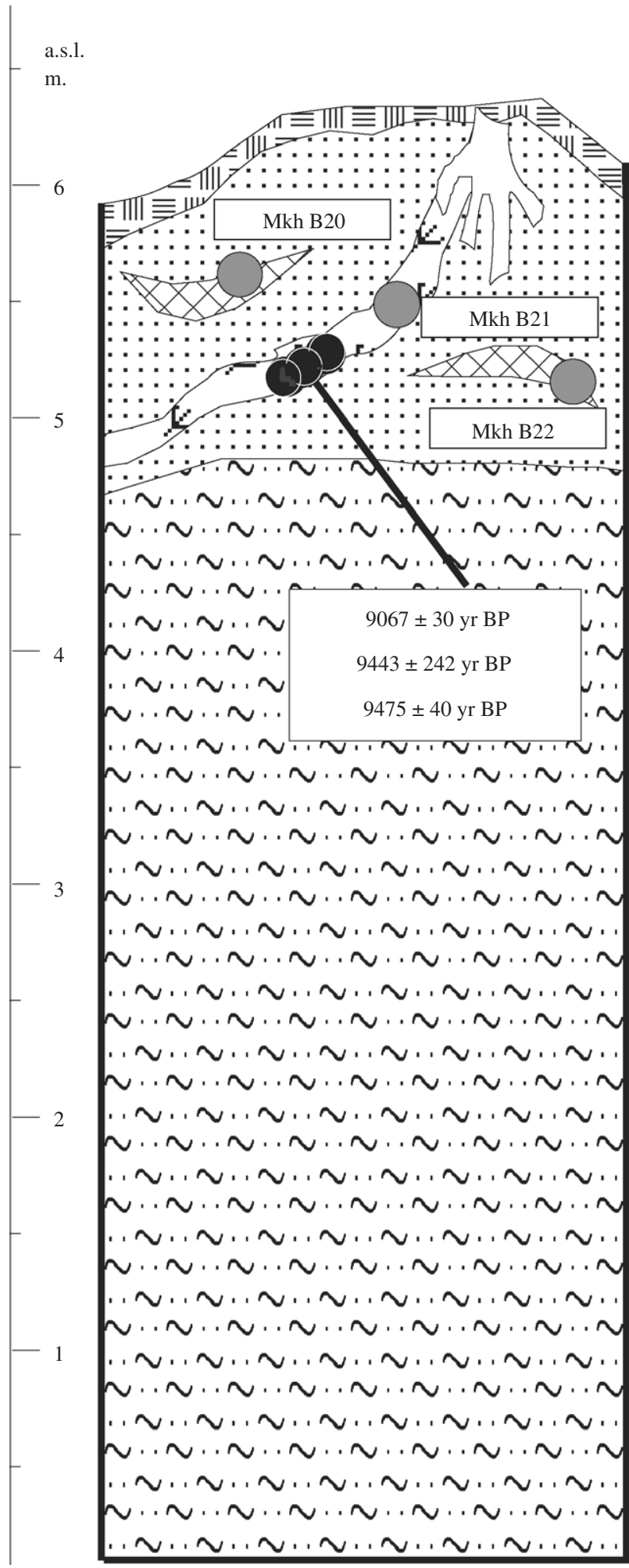

Fig. 4. The Mamontovy Bysagasa section, Bykovsky Peninsula.

origin, while the upper combines the features of alass and fluvial sedimentation. This is interpreted to mean that the formation of the alass was combined with a local creek activity. Large wood stumps in growth position indicate that trees grew on the flood-plain of that creek.

\subsubsection{Top-Yedoma "pockets"}

Regular insertions ("pockets") of organic-rich icy silt have been described and sampled in the upper part of the Mamontovy Khayata Ice Complex section (Fig. 1, Site 1; Fig. 5A-D). In 1999, we have sampled peat inclusions within one of these "pockets" (Fig. 5A) at a depth of $1.5 \mathrm{~m}$ ( $37.5 \mathrm{~m}$ a.s.1.) and at $2.5 \mathrm{~m}$ (Sher et al., 2000). These samples yielded AMS ${ }^{14} \mathrm{C}$ dates of $7520 \pm 50 \mathrm{yr}$ BP (KIA 10352 ) and $7790 \pm 50 \mathrm{yr}$ BP (KIA 10353), respectively. Peat inclusions occurred in silt with extremely high ice content. The insect sample, MKh99-3aC, was screened at the same place as the lower sample. The AMS date of $12,790 \pm 60 \mathrm{yr}$ BP (KIA 10355) was obtained $0.5 \mathrm{~m}$ below this level. It comes from a silt with much lower ice content, which contains no peat, but in situ grass roots (the dated object), typical for Ice Complex sediments. Thus, there is a break in sedimentation (in this case, about $5000 \mathrm{yrs}$ long) between the Ice Complex and the early Holocene "pocket".

In 1998, a series of ${ }^{14} \mathrm{C}$ samples was taken from a near-by "pocket" by the members of the Russian-German Expedition. The dates obtained are 10,840 \pm 50 (KIA 11441), $8230 \pm 50$ (KIA 6720) and $8050 \pm 187 \mathrm{yr}$ BP (PI-2001) (Schirrmeister et al., 2002a). Peat was the dated material in all cases, but the second sample also included wood. Unfortunately, the spatial relationship of these samples is not quite clear. According to the field sketch of H. Meyer (pers. comm.), they all come from a peat-rich "pocket" between large ice wedges or $(8230 \pm 50)$ from a peat block inserted into the ice wedge (Fig. 5A). Meyer et al. (2002) refer these samples to the "uppermost part of Ice Complex", but our subsequent 2 yrs of work at the section showed that wood and large peat inclusions do not occur in the upper part of the Mamontovy Khayata Ice Complex, but rather belong to the Holocene "pockets". However, the date $10,840 \pm 50 \mathrm{yr}$ BP is uniquely old for such "pockets", and should be taken with caution. Finally, the thin layer overlying the large ice wedges at the top of the cliff was dated to $300 \pm 50 \mathrm{yr}$ BP (KIA 11442, Meyer et al., 2002).

In 2001, we observed the process of rapid thermodenudation of the upper part of the cliff in exactly in the same area (Sher et al., 2002a, b). The peat-rich "pockets" were being separated from the cliff, forming the top of the baydzherakhs ${ }^{4}$ of the upper level, the base of which was formed of Pleistocene sediments (Fig. 5C, D). Three insect samples have been obtained from such a baydzherakh: MKh-01-01, MKh-01-02, and MKh-01-03 (at the elevations of 37.6, 37.3, and $36.4 \mathrm{~m}$ a.s.l., respectively) (Sher et al., 2005). The latter sample, coming from the Pleistocene base of the baydzherakh, yielded an insect assemblage strikingly different from that of the upper (Holocene) samples (see below).

A very similar geological situation was observed at the top of the BKh on Kurungnakh Island (Fig. 1, Site 2;

\footnotetext{
4"Baydzherakhs" or "thermokarst mounds" is the term accepted in permafrost literature for ground mounds remaining after the adjacent ice wedges had thawed.
} 

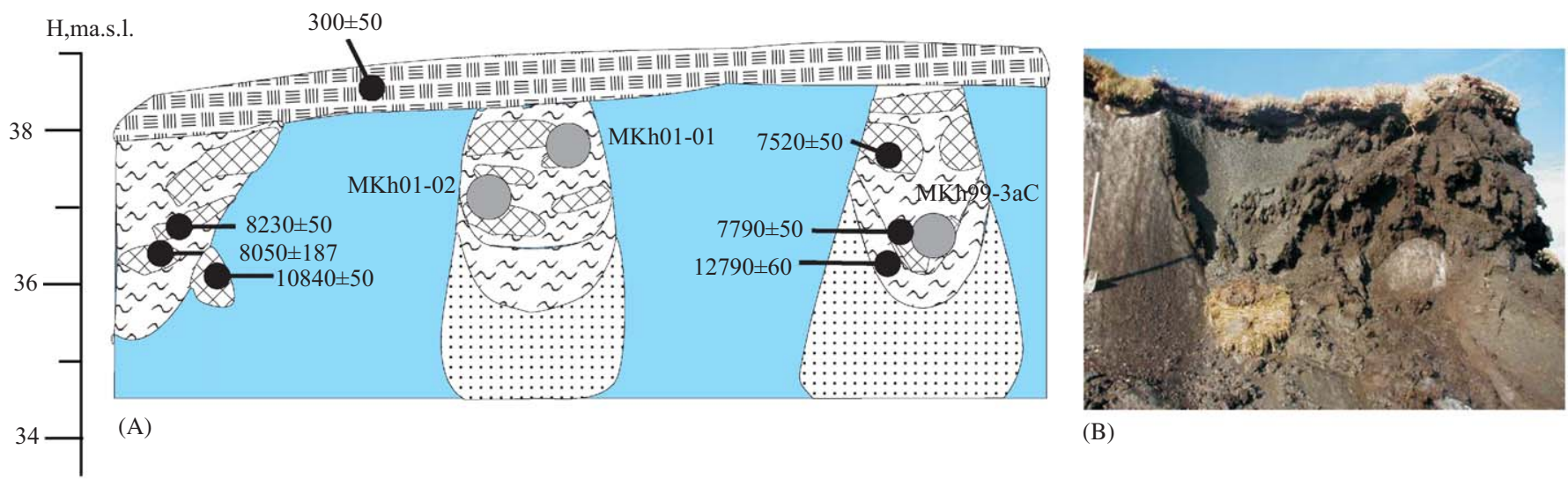

(B)

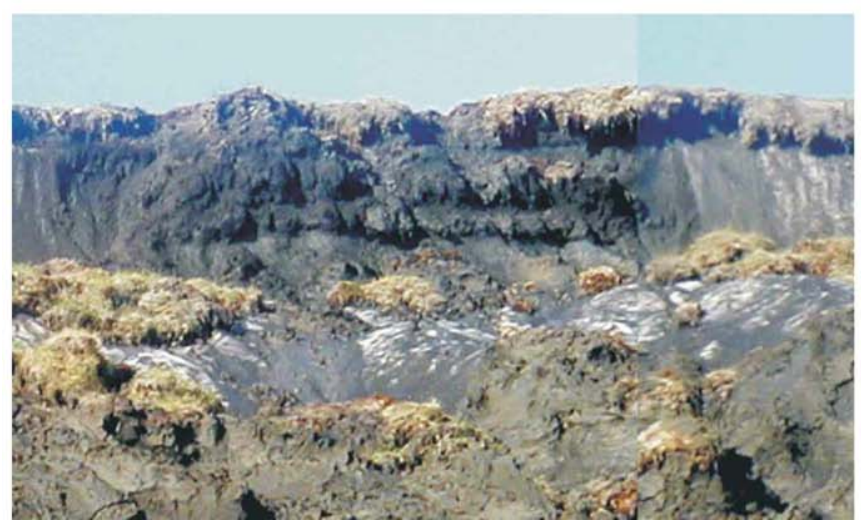

(C)

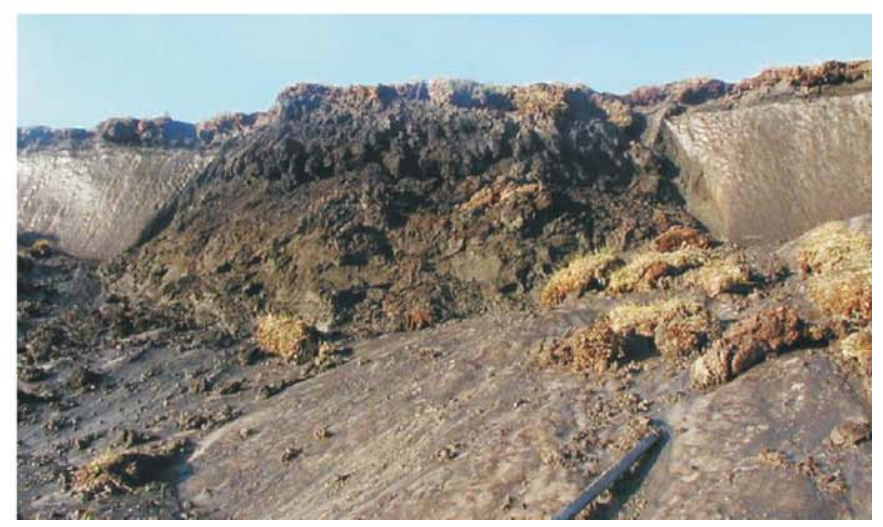

(D)

Fig. 5. Mamontovy Khayata section, Bykovsky Peninsula. The Holocene "pockets" on the top of the partially eroded Ice Complex surface. (A) Combined sketch of 1998, 1999, and 2001 sampling areas. (B-D) Peat inclusions in Holocene "pockets" (C, D) successive stages of transformation of a "pocket" into baydzherakh in course of thaw.

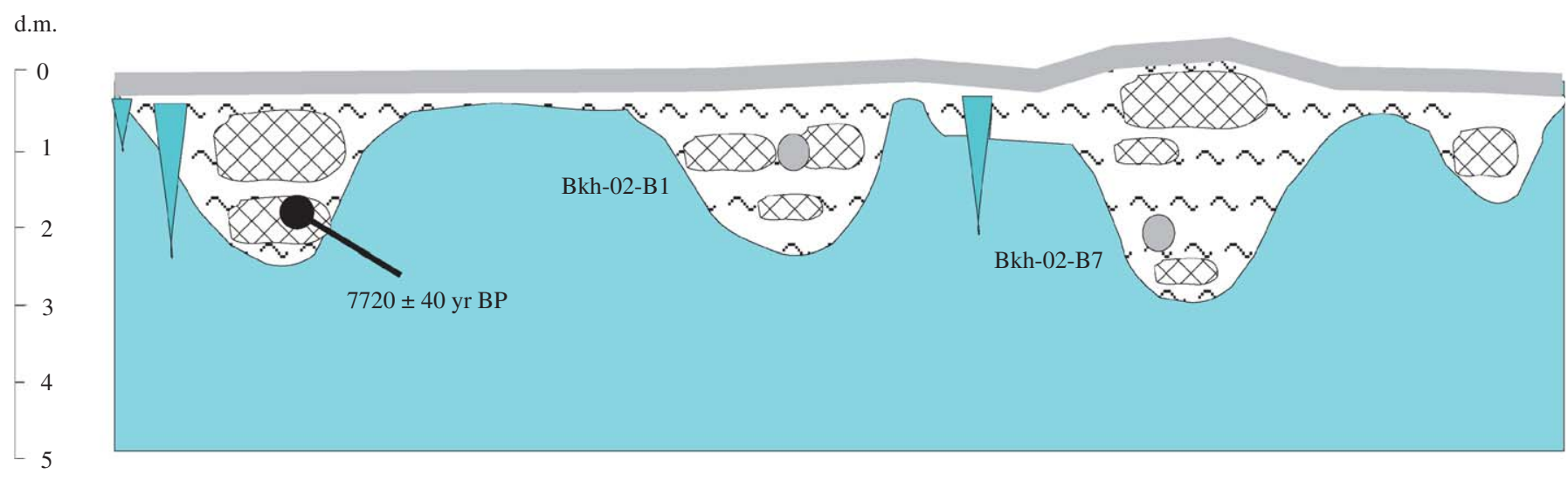

Fig. 6. Top of the Byor-Khaya section, Kurungnakh Island, Lena Delta-Holocene sediments with peat inclusions into Pleistocene ice wedge, cut along the strike.

Fig. 6). Peat from one "pocket" has been dated to $7720 \pm 40$ yr BP (KIA 12596, Schirrmeister et al., 2003). The insect samples BKh-02-B1 and BKh-02-B7 were obtained from a similar part of a near-by "pocket".

The top of Ice Complex on Bolshoy Lyakhovsky Island also exposes numerous "pockets", rich with peat and wood remains. One of them was dated $7370 \pm 820 \mathrm{yr}$ BP (NUTA2840) (Nagaoka et al., 1995). Other (still unpublished) dates confirm the same time-range for the "pockets," as in Mamontovy Khayata (9000-7000 yr BP).

\subsubsection{River terraces}

A section of the first terrace above the flood-plain of the Lena River was studied on the little island of Arga-BilirAryta (Fig. 7), near Kurungnakh-Sise Island in the Central Lena Delta (Kuzmina and Bolshiyanov, 2002). The terrace 

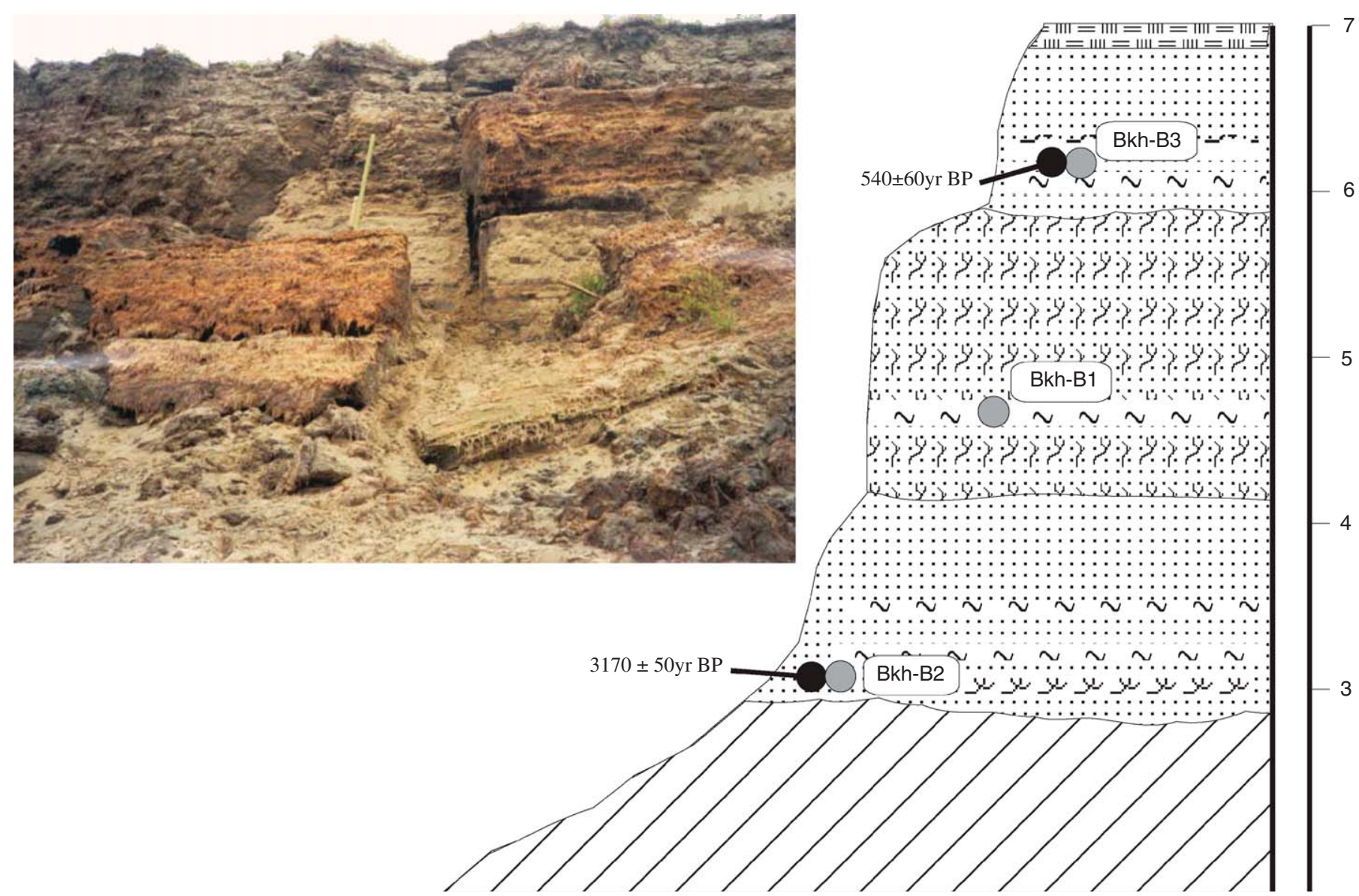

Fig. 7. Late Holocene flood-plain terrace, Kurungnakh Island (Arga-Bilir-Aryta site), the Lena River Delta

is $7-10 \mathrm{~m}$ high, and is not affected by modern floods (no driftwood on the surface). The lower part of the section (3-4 $\mathrm{m}$ above the river) is composed of fine and coarse sand alternating with silt layers rich with plant detritus. Its conventional ${ }^{14} \mathrm{C}$ age is $3170 \pm 50 \mathrm{yr}$ BP (LU-4609, Kuzmina and Bolshiyanov, 2002). The insect sample BKh-B2 was obtained here. The section interval of 4 to $6 \mathrm{~m}$ above the river consists of sandy silt and silt layers intercalalated with plant detritus layers. The insect sample from here (BKhB1) was unexpectedly poor in specimens. The upper part of the section (sand with plant detritus) provided the date of $540 \pm 60 \mathrm{yr}$ BP (LU-4565, Kuzmina and Bolshiyanov, 2002) and a poor insect sample, BKh-B3.

The low terrace at the Zimovye River mouth (Bolshoy Lyakhovsky Island) is composed of sand with silt and plant detritus lenses (Fig. 8). There are no radiocarbon dates for this section, but it definitely belongs to the latest Holocene, as the terrace is cut into the alass surface. Three insect samples (LL-1-B23, B24 and B25) have been obtained at different levels of the section (Fig. 8).

To summarize, the existing evidence shows that sedimentation in the alasses and alass terraces in the Laptev Sea region started about $9500 \mathrm{yr}$ BP. This sedimentation

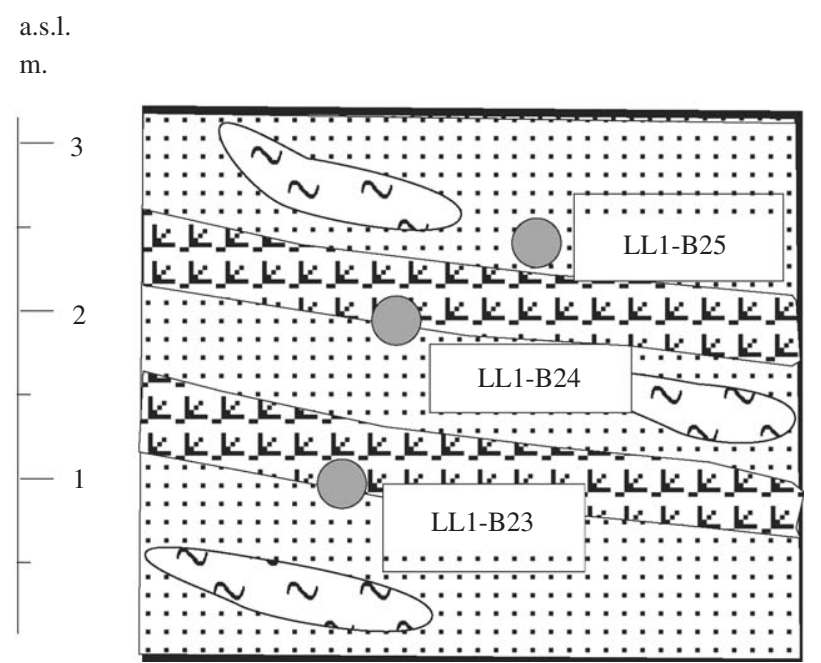

Fig. 8. Late Holocene flood-plain terrace of Zimov'e river on Bolshoy Lyakhovsky Island.

continued through the early Holocene, and was marked by the presence of tall shrubs on Bolshoy Lyakhovsky Island and trees in the central and eastern Lena Delta. In the 
lower parts of the alass sections there are almost no dates younger than $7500 \mathrm{yr}$ BP. During that time $(9500-7500 \mathrm{yr}$ BP) the active thermodenudation of Ice Complex continued, and tall shrubs (alder, birch, willow) grew on the high land surface. Surpisingly, the rather long list of recently obtained ${ }^{14} \mathrm{C}$ dates from the region (more than 40 , including those still unpublished) has practically no middle Holocene dates. The second group of dates belongs to the late Holocene (upper parts of alass sections and low river terraces), starting from $3700 \mathrm{yr}$ BP. The middle Holocene "gap" can probably be explained by the fact that the early Holocene flourishing of shrub vegetation was over by about $7500 \mathrm{yr}$ BP. Because of the sharply decreased organic component (so important in the early Holocene), sedimentation rates slowed down. This is probably one of the reasons why we could not find any middle Holocene insect faunas in the Laptev Sea region.

\section{Results}

The earliest Holocene fossil insect assemblages studied from the Laptev Sea region date from the interval 9500-9000 yr BP in the alass terrace on Bykovsky Peninsula (see Section 3.2.2., Fig. 1, Site 1). Several insect samples of standard size were screened from the MB section. The lower samples come from the Taberal Unit and have a faunal composition typical of the late Pleistocene asssemblages (Kuznetsova et al., 1999). Three samples were screened from the upper unit (Fig. 4), one of them being relatively small, while samples Mkh-B21 and B20 each yielded more than 100 insect individuals. These samples have been taken from sediments rich in plant remains, including thick shrub branches. Their age therefore closely corresponds to the radiocarbon dates obtained from the organic-rich samples submitted for dating (9475-9067 yr BP). Both samples are very similar in faunal composition. The insect assemblages (see table in the online version of this article) contain mostly mesophilic tundra species (55-56\%), dominated by the ground beetle Pterostichus (Cryobius) brevicornis. There are also some taiga species, aquatic and riparian insects. The fauna includes some species that very rarely or never occur in Pleistocene assemblages in northeastern Siberia. These are the ground beetles Carabus vietinghoffi, Nebria frigida, and Loricera pilicornis, seven rove beetle species, and the leaf beetle Phratora vulgatissima. Unexpectedly, we also found a few representatives of xerophilous taxa, and even steppe species, which are characteristic of the Pleistocene tundrasteppe assemblages. The pill beetle Morychus viridis represents $5 \%$ of all individuals in the sample. True steppe species are represented by single individuals, including the weevil Stephanocleonus eruditus the leaf beetle Galeruca interrupta circumdata, and the soft-winged flower beetle Troglocollops arcticus. The latter species is indicative of meadow-steppe habitats.

Although the former presence of larch, shrub birch and alder, and tall willows is documented in this section by well-preserved plant remains, true forest insects (such as long-horned or bark beetles) are absent. A few "taiga" species from this fauna (Loricera pilicornis and others) are not directly tied to trees. Rather, they may have lived in open spaces in the taiga, such as meadows and river floodplains. To summarize, this early Holocene insect assemblage is indicative of an open landscape with sparse trees. The landscape probably had a similar appearance to modern forest-tundra, but was not a complete analogue of it. The insect faunal composition clearly indicates higher humidity than in the Pleistocene, while the presence of trees and tall shrubs probably suggests higher summer warmth than today. On the other hand, if at least some of the occasional thermo-xerophilic species were really present in situ (not redeposited), that would suggest the existence of well-heated and dry habitats.

Sample BKh-B4, from the lower part of the Buor-Khaya alass (Fig. 1, Site 2; Fig. 3) is a little younger $(8600-8300 \mathrm{yr}$ BP). It comes from the sediment very rich with shrub and wood remains, including alder and tree birch (cf. Section 3.2.1). The sample is not very large, but includes fossils of more than 25 insect taxa (see table in the on-line version of this article). The assemblage is dominated by mesophilic tundra species. The abundance of the rove beetle Olophrum consimile (35\% of all individuals) indicates boggy terrain, but rather in southern (shrub) tundra or forest tundra. There are several species associated with willows, such as the leaf beetles Chrysomela blaisdelli and Phratora vulgatissima, and the weevil Dorytomus rufulus amplipennis. A single fossil of the bark beetle Polygraphus sp. associated with conifers (most likely, larch) is the only entomological evidence of trees in the environment. A few relatively thermophilic species, such as the ground beetle Diacheila polita, and rove beetles Eucnecosum sp. and Stenus sp. give additional indication of rather mild environmental conditions of forest-tundra. The presence of the soft-winged flower beetle Troglocollops arcticus (a single fossil), is in contrast with generally hygro-mesophilic character of the assemblage. This beetle, however, has very fragile exoskeleton, and it seems unlikely that the fossil is redeposited or experienced long-distance transport. It can be found today even in the high Arctic (e.g., on Wrangel Island), but only in the driest and warmest of habitats. The existence of such patches around the former lake is also confirmed by the presence of other tundra xerophiles, such as the weevil Hypera ornata.

A series of insect samples of slightly younger age: $8230-7520$ yr BP, was obtained from the Holocene sediments from the top of the Mamontovy Khayata Ice Complex section (Fig. 1, Site 1, Fig. 5). Two samples, MKh-01-01 and MKh-01-02, are rich in insect fossils (see table in the on-line version of this article). They are similar in ecological structure to each other and to sample MkhB21 from the MB section, discussed above. Both samples are dominated by mesic tundra inhabitants $(58-60 \%)$, the most abundant being Pterostichus (Cryobius) brevicornis (38-44\% of the whole assemblage). The samples show 
rather high percentages of aquatic and riparian insects (17-18\%), and in the poor sample MKh99-3aC (see table in the on-line version of this article) this group peaks at $60 \%$. In small closed ponds, where the sampled peat inclusions were formed (see Section 3.2), the local aquatic inhabitants are buried in place and often become overrepresented in the fossil assemblage. The abundance of aquatic insects in such assemblages (as discussed by Kuzmina, 2001) cannot be considered as a signal of a higher regional humidity, because they are obviously taphonomically biased. Dry tundra species constitute $12 \%$ of the assemblage. Typical "tundra-steppe xerophiles" are present, but in very small numbers. Each sample contains the fossils of 4-5 individuals of Morychus viridis. The steppe weevils Stephanocleonus spp., and the dung beetles Aphodius sp. are represented by single fossils. As in the previous sample, the species associated with trees and shrubs, or currently living in taiga, are surprisingly rare. There are species that have never been found in the Pleistocene assemblages of this region, such as the taigazone carrion beetles Phosphuga atrata and Aclypea opaca, and the carpenter ant Camponotus herculeanus.

Two insect assemblages of similar age $(7720 \pm 40 \mathrm{yr} \mathrm{BP})$ and taken from a similar geological setting, were obtained in the Central Lena Delta from the Buor-Khaya section (Fig. 1, Site 2; Fig. 6). The faunal composition of sample Bkh-02-B7 (see table in the on-line version of this article) resembles the previously discussed samples. The mesophilic tundra group (mostly Pterostichus (Cryobius) brevicornis) clearly dominates here $(72 \%)$. Also, there are some taiga species, such as the ground beetle Notiophilus sylvaticus. This species, as well as the ground beetle Diacheila polita and weevils Dorytomus spp., are typical of the Holocene assemblages, but are very rarely or never encountered in the Pleistocene faunas from this region. The sample BKh02-B1, obtained a little higher in the section of the near-by "pocket", is very similar in composition to the previous one, down to minor details. For example, only these two samples in all our collection contain fossils of the ground beetle Notiophilus sylvaticus and the rove beetle Holoboreaphilus nordenskioeldi. Both of these species are very rare in Arctic Siberia, past and present. These similarities not only suggest that both samples are quite close in age (though taken at slightly different elevation in the section), but also that they really reflect the past insect species composition. The sample BKh-02-B1 is also interesting in having the highest percentage of taiga species among all Holocene samples from the region $(15 \%)$. However, like in the other assemblages, these taiga species do not rely directly on trees and under appropriate climatic conditions are capable of inhabiting open spaces.

An interesting early Holocene insect assemblage comes from the alass section LL-17 on Bolshoy Lyakhovsky Island (Fig. 1, Site 3; Fig. 2). The insect assemblage (sample LL-17-B20, see table in the on-line version of this article) is also dominated by the mesophilic tundra group (51\%), followed by dry tundra inhabitants $(16 \%)$, represented mostly by the ground beetle Curtonotus alpinus. Rather unexpectedly, the fossils of Morychus viridis, a typical species of hemicryophytic steppe, are quite abundant $(16 \%)$, and there are single remains of some steppe, meadow-steppe and xerophylic insects, such as Stephanocleonus eruditus, Troglocollops arcticus, Coniocleonus sp., Notiophilus aquaticus, and Aphodius sp., each represented by one individual. A number of relatively thermophilic species were also found. These beetles live today mostly in the taiga zone, but also occur in southern (shrub) tundra. They include the ground beetle Dyschiriodes nigricornis, the ant Leptothorax acervorum, and a rove beetle Lathrobium sp., but they are all also represented by single individuals in the sample. We found no insect species directly associated with the trees in this assemblage.

Unfortunately, no middle Holocene insect faunas have been so far found in the Laptev Sea area, so our record has a gap between 7500 and $3700 \mathrm{yr}$ BP. Late Holocene fossil insects were studied on Bolshoy Lyakhovsky Island and in the Lena Delta. Sample LL-17-B21 comes from the upper part of the alass section on the Island (Fig. 2, see table in the on-line version of this article). Although the sample yielded less than 50 insect individuals, the composition of the insect assemblage is quite different from the early Holocene sample from the same section (LL-17-B20). The late Holocene sample is dominated by arctic tundra insects. There are several arctic leaf beetles of the genus Chrysolina, such as C. wollosowiczi (dominant), C. tolli, and C. bungei. The rove beetle Tachinus arcticus is rather abundant. This is a very common species in the northern tundra today, preferring mesic habitats. The rich samples of modern beetles collected by SK in this area in 1998 show that all the species listed above occur today on Lyakhovsky Island, and in about the same quantitative proportions as in the fossil assemblage.

Three insect samples of even later Holocene age come from the low terrace of the Zimovye River in the same area (Fig. 8, see table in the on-line version of this article). Sample LL-1-B23 is rather poor, but the other two (LL-1B24 and B25) are rich enough to clearly define the type of assemblage. All samples have the same common features, so we can consider them together. They are all dominated by mesophilic tundra species (48-68\%), have consistent numbers of dry tundra inhabitants (12-24\%) and a variable percentage of arctic tundra species (1-8\%), such as the leaf beetles Chrysolina subsulcata and C. wollosowiczi, and the willow weevil Isochnus arcticus. On the other hand, they all include various species that definitely do not live on this island now, and/or could hardly live in such a severe environment. Such species are present even among the dominant group of tundra mesophiles, e.g. the ground beetle Diacheila polita, the rove beetles Olophrum consimile and Eucnecosum sp., and the pill beetles Curimopsis cyclopedia and Simplocaria arctica. The same is true for such riparian insects as the ground beetle Elaphrus riparius and the weevil Tournotaris bimaculatus, the meadow leaf beetle Phaedon concinnus, and xerophilic ground beetle 
Notiophilus aquaticus. The dry tundra weevils Hypera ornata and Sitona borealis are even less compatible with the present climate and vegetation of the island. They feed on legumes that do not grow here today. Likewise incompatible are the shrub weevils Lepyrus nordenskioeldi and Dorytomus imbecillus. Moreover, all three samples contain 5-8\% of specimens of the hemicryophytic steppe beetle Morychus viridis. Furthermore, sample LL-1-B25 has a striking percentage of the true steppe weevils Stephanocleonus eruditus and S. fossulatus. $(7.7 \%)$.

Since almost all of the afore-mentioned beetles are "exotic" to the present fauna of Bolshoy Lyakhovsky Island, but were quite common in the Pleistocene tundrasteppe faunas, the three samples from the low terrace may contain a mixture of Holocene and Pleistocene assemblages. The Zimovye River, in its lower course, meanders among the Ice Complex (Yedoma) hills and alasses, consistently eroding their sediments, so the Late Pleistocene and early Holocene units are the main source of material for the fluvial deposits, including the low terrace. Hence, a significant number of fossils of those ages are delivered to the river, and the possibility of their inclusion in late Holocene assemblages is rather high. The problem of insect fossil redeposition in permafrost environments is discussed in more detail in Section 5.2, below (Fig. 9).

Very different late Holocene insect assemblages have been found in the Lena Delta. Sample Bkh-B2 $(3170 \pm 50 \mathrm{yr}$ BP) comes from the lower part of the section of the first terrace above the flood-plain (cf. Section 3.2.4.; Fig. 1, site 2; Fig. 7) (Kuzmina and Bolshiyanov, 2002). This sample is rather small, but the fauna is quite diverse, and includes the members of all ecological groups except for steppe (see table in the on-line version of this article). The mesophilic tundra group has the highest percentage $(28 \%)$. The second most dominant group is composed of species from three ecological types, combined here as the "foresttundra" group (shrub, taiga, and meadows); together they comprise $25 \%$ of the assemblage. Riparian and aquatic species are also abundant $(22 \%)$. Dry tundra beetles constitute nearly $12 \%$. The rest of the groups show low percentages $(1-2 \%)$. The assemblage includes many species that are quite common in Holocene faunas and relatively rare occur in Pleistocene ones. These are the ground beetles Pelophila borealis, Nebria frigida, Blethisa catenaria, and Diacheila polita, a rove beetle Eucnecosum sp., the dung beetle Aegalia kamtschatica, the click beetle Hypnoidus hyperboreus, and the weevils Grypus mannerheimi and Sitona lineellus. The group of species associated with shrubs is more diverse than is usually observed in tundrasteppe communities, and includes such relatively thermophilic species as the leaf beetles Chrysomela blaisdelli, Gastrolina peltoidea, and Gonioctena affinis. Their modern distribution is mostly restricted to the forest zone, and they usually do not occur north of the southern (shrub) tundra sub-zone. Some meadow species (e.g., the leaf beetle a.s.1

m.

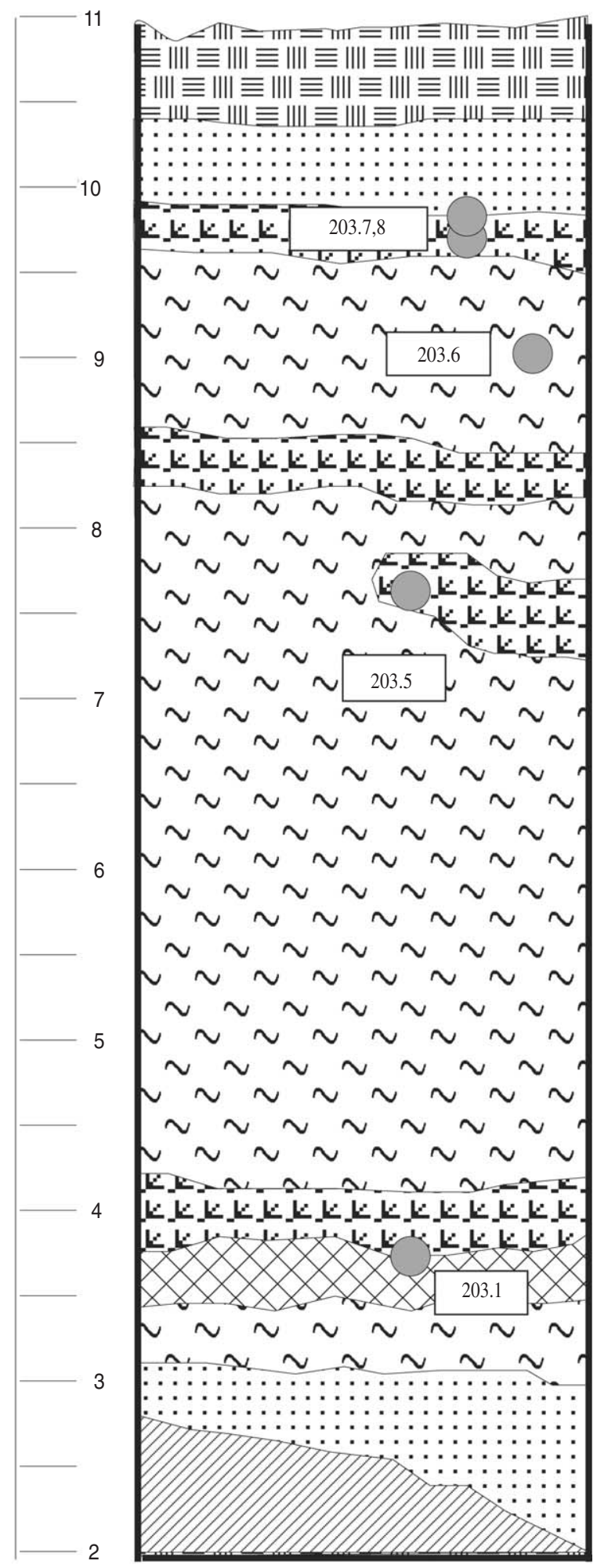

Fig. 9. Section of the first flood-plain terrace of Alazeya River, Kolyma Lowland.

Gastrophysa viridula) and riparian species (e.g., the weevil Lixus paraplecticus) are also not currently known from north of the taiga zone. The assemblage also includes some 
typical taiga species that live under bark or in wood, such as the ground beetle Dromius quadraticollis, the carrion beetle Phosphuga atrata, and the carpenter ant Camponotus herculeanus. Single fossils of xerophilic insects, such as Morychus viridis and Aphodius sp. could have been transported from the patches of steppe habitat not very far upstream. In particular, one such site, Belaya Skala (the White Rock), a south-facing slope of the Lena River valley (Fig. 1), still hosts one of the relict populations of Morychus viridis. ${ }^{5}$

In general, this late Holocene assemblage indicates that taiga vegetation existed at least in close proximity to the fossil site, if not at the site itself. This situation is not very much different from the present one, since the northernmost larch forest outpost in the Lena valley is only $60 \mathrm{~km}$ to the south (see Fig. 1 and Section 3.1), but the presence of many thermophilic species suggests that the local climate may have been a little warmer and less continental than it is today.

The younger samples from the same terrace section (BKh-B1, B3, see table in the on-line version of this article) are very small and include only species that are currently known in the area.

The environmental evidence from the Holocene insect faunas in the Laptev Sea region may be summarized as follows. The early Holocene insect assemblages (ca 9500-7500 yr BP) were different from the modern ones, but differ much more greatly from the late Pleistocene assemblages. In the three different study regions, they are alike in their general composition, being strongly dominated by mesic tundra insects, and even by the same species, Pterostichus (Cryobius) brevicornis. Unlike modern tundra assemblages, they all include minor percentages of species that are currently restricted to taiga or foresttundra, but only a few insects were found that clearly indicate the presence of trees (e.g., xylophages). The third common feature of the early Holocene faunas is the consistent presence of relatively thermophilic xerophiles. However, these were found in very small numbers, and are many times less than those found in terminal Pleistocene assemblages (except for Morychus viridis in the Bolshoy Lyakhovsky section). The possibility of their redeposition from Pleistocene units must be carefully considered (see Discussion below). If at least some of the occasional thermo-xerophilic species were really present in the early Holocene (not redeposited), then we are dealing with assemblages that have no modern analogue. The late Holocene insect assemblages (ca 3700-3100 yr BP) reflect the modern environment of the corresponding regions much more closely than the early Holocene ones. Because of this, they also clearly demonstrate the pattern of the present-day latitudinal zonality in the Laptev Sea area.

\footnotetext{
${ }^{5}$ Modern insect collection of the Lena Delta Nature Reserve Museum, Tiksi. Collector A. Tsibul'sky, identified by B.A. Korotyaev.
}

\section{Discussion}

Our knowledge of the history of the insect fauna of the last $15 \mathrm{kyr}$ of the Laptev Sea region is far from complete. So far, three quite different types of regional insect assemblages are known for this period. The fauna of the latest Pleistocene, until at least $12,500 \mathrm{yr} \mathrm{BP}$, was quite clearly of the "tundra-steppe" type (Sher et al., 2005). It was dominated by relatively thermophilic xerophiles, and included true steppe species; its tundra component was dominated by dry site inhabitants, rather than mesic tundra beetles (Fig. 10). In contrast, the early Holocene fauna (ca 9500-7500 yr BP) is remarkably different, as it is strongly dominated by mesophilic tundra species. It is not totally similar to the modern insect fauna of the region, however. No fossil insect assemblages are known from the time between these two types. The gap in the record (about $3000 \mathrm{yrs}$ long) prevents us from understanding the processes of environmental change during the Pleistocene/ Holocene transition. The third type, the late Holocene fauna (ca 4000-3000 yr BP and later), is much more similar to the modern faunas, though it could reflect slightly more favorable conditions than today. No middle Holocene insect faunas are known in the region, and this gap in the record is also about $3000 \mathrm{yrs}$ long. As discussed above, natural phenonena may, at least in part, explain the existence of both gaps. These processes include sharply increased activity of thermo-erosional processes at the Pleistocene/Holocene boundary and a dramatic decrease of biomass production at the end of the early Holocene.

The first gap is much more important and challenging, as it conceals the most dramatic transformation of insect fauna and environment. Because we are unable to trace it, step by step, in the fossil record, the only remaining approach in developing our understanding of this transition is to compare the fossil insect data from the either side of it.

\subsection{The comparison between the early Holocene and the late Pleistocene insect assemblages}

\subsubsection{Ecological structure}

The most common feature of the Pleistocene assemblages is their complex character, i.e. combinations of ecological groups that can scarcely be found today. Most Pleistocene assemblages are of a non-analogue type, combining arctic, steppe, and sometimes boreal species. Xerophilic insects dominate many assemblages, and thermophilic xerophiles are common. The marked dominance of one xerophilic species in an assemblage, most frequently Morychus viridis, is quite common. These features lead us to refer these assemblages to the "tundra-steppe" type in a broad sense, and to try to interpret the variations in the ecological structure of the assemblages as different variants within that type, probably related to the regional variations in summer temperature (Kuzmina, 2001; Sher et al., 2005). 


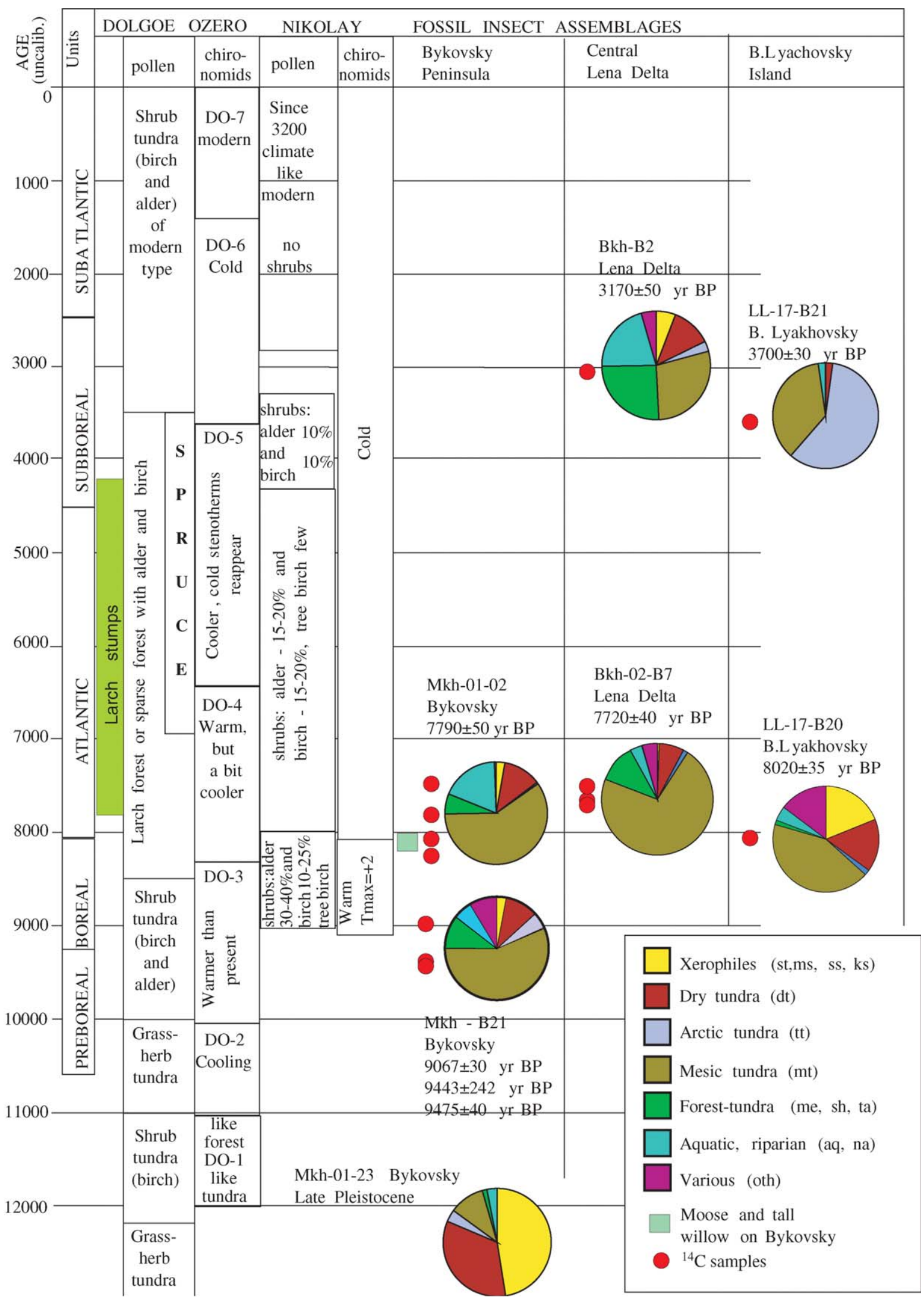

Fig. 10. Correlation of environmental records in the Lena Delta (Dolgoe Ozero and Nikolay Lakes) and the ecological structure of the Pleistocene and Holocene fossil insect assemblages from the Laptev Sea region. Dolgoe Ozero - after Pisaric et al. (2001) and Porinchu and Cwynar (2002). Nikolay Lake - after Andreev et al. (2004b).

Ecological groups of insects: 1-xerophiles (st,ms, ss, ks), 2-dry tundra (dt), 3-arctic tundra (tt), 4-mesic tundra (mt), 5-forest-tundra (me, sh, ta), 6 - aquatic, riparian (aq, na), 7-various (oth), 8- Moose and tall willow on Bykovsky; $9{ }^{14} \mathrm{C}$ samples. 
Despite these variations, the tundra-steppe assemblages kept their basic features over the vast area of East Siberia, apparently regardless of latitude. A few late Pleistocene fossil faunas have thus far been studied from sites much further south, such as Ust'-Omchug (Fig. 1, site 18) and the Dima Baby Mammoth site in the Kolyma headwaters (Fig. 1, site 19), and Aldan in Central Yakutia (Fig. 1, site 20), but they are quite similar to those of the present Arctic coast (Kiselyov, 1995; S. Kuzmina, unpublished data). A very broad south-to-north distribution of open grassand-herb dominated vegetation (tundra-steppe, in our sense) is also inferred from the Late Pleistocene pollen record (Anderson and Lozhkin, 2002).

In contrast to the above, the Holocene assemblages have an ecological structure that is more similar to present-day insect communities. The Holocene assemblages never include large numbers of xerophilic species, and in most cases the insects associated with shrubs are much more common than in Pleistocene assemblages. The Holocene assemblages are not dominated by "exotic" species, such as the pill beetle Morychus viridis, or weevils of the genus Stephanocleonus, which are so typical of the Pleistocene assemblages (Kiselyov, 1981; Kuzmina, 1989, 2001). If relatively thermophilic "exotic" species occur in the Holocene assemblages, they are mostly the modern-day inhabitants of the taiga, but not the steppe zone. The Holocene fossil assemblages can be dominated by a single species, but such species currently live in the given study region (e.g., Pterostichus (Cryobius) brevicornis in the regions bordering the Laptev Sea). However, our results suggest that the early Holocene faunas were also to some extent of non-analogue character (see below).

\subsubsection{Taxonomic diversity}

The Pleistocene insect faunas of northeastern Siberia are characterized by low taxonomic diversity. This can be

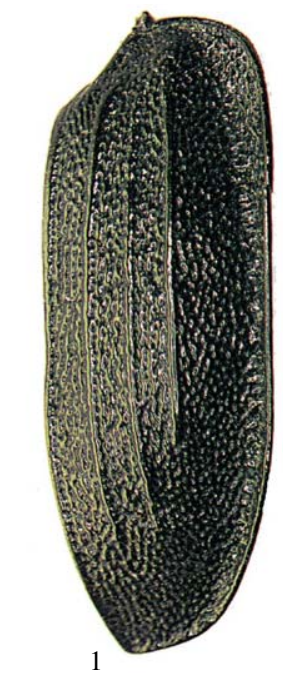

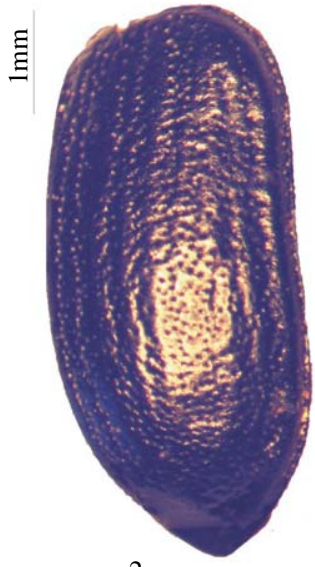

2
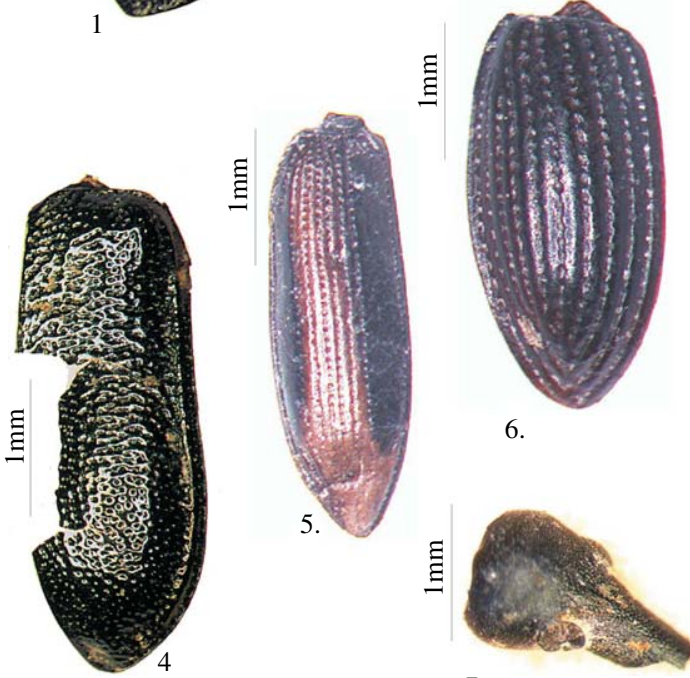

6.

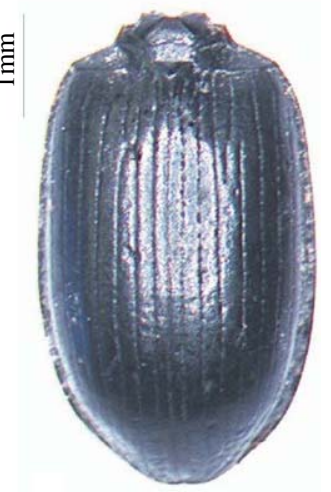

3

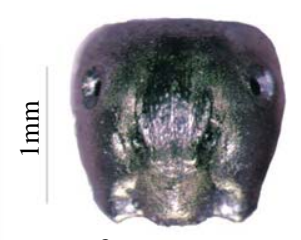

8
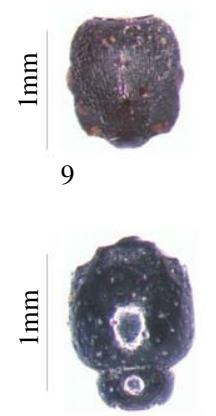

10

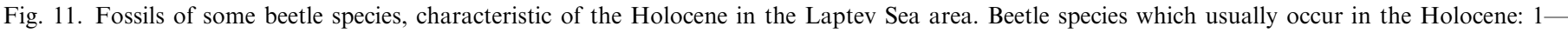

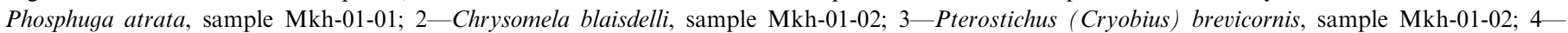

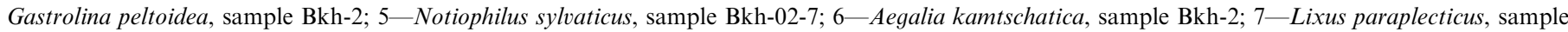

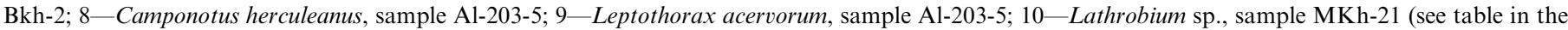
on-line version of this article). 
partly explained by the relatively narrow amplitude of the environmental changes through time, which caused a high degree of faunal continuity, even between the assemblages of different climatic epochs. As a result, most Pleistocene assemblages include a more-or-less permanent "core" of about ten common species, each of which is found in more than $50 \%$ of all fossil assemblages with MNI $>50$.

The taxonomic composition of the early Holocene faunas is usually more diverse (Fig. 11). For example, each of three latest Pleistocene fossil insect assemblages from the Bykovsky Ice Complex section, totalling 170-250 individuals, includes only 25-30 species (Sher et al., 2005). The early Holocene samples of smaller size (120-160 individuals) each include 38-40 species, and in larger samples $(300-400)$ the number of species is about 50 (see table in the on-line version of this article).

The most remarkable feature of the early Holocene assemblages is that they include numerous species that are rarely if ever encountered in regional Pleistocene faunas. That is true even at the higher (family) taxonomic level. The first of these are the groups of insect families associated with wood. These include beetles of such families as Ostomatidae (bark-gnawing beetles represented by Thymalus oblongus), Bostrichidae (branch and twig boring beetles-Stephanopachys substriatus) (the Holocene site on the Medvezhyi Islands, Fig. 1, site 11, Kuzmina and Kolesnikov, 2000), and Scolytidae (bark beetles). Some tree-associated taxa from other families, such as the ground beetle Dromius quadraticollis, or the weevils Hylobius piceus and Pissodes spp., are also known only from Holocene faunas, but these are represented by single fossils. It should be noted that some tree-associated taxa are very abundant in modern taiga, and even in forest-tundra, but have never been encountered as fossils (e.g., long-horned beetles (Cerambycidae), such as Monochamus spp.). Secondly, the diversity of leaf litter-associated beetles increases sharply in the Holocene. For example, the diversity of Staphylinidae (rove beetles) is especially impressive when compared to their paucity in the Pleistocene. More than 20 species of this family are recorded in the Holocene assemblages, while only two of them are common in the Pleistocene (Tachinus arcticus and $T$. brevipennis), and others are either very rare or absent. The occurrence of some other families, such as Heteroceridae (variegated mud-loving beetles), Elateridae (click beetles), Coccinellidae (ladybird beetles), and Silphidae (carrion beetles) is also characteristic of Holocene assemblages. Some "typical Holocene" species include the ground beetles Carabus canaliculatus, Pelophila borealis, Nebria frigida, Blethisa catenaria, and Elaphrus lapponicus. Among the "typical Holocene" leaf beetles are members of the genera Donacia, Chrysomela, Cassida, Luperus, and Altica, and species such as Bromius obscurus, Gastrophysa viridula, Gonioctena affinis, Phratora vulgatissima, and Prasocuris phellandrii. Pill beetle species that are only known from Holocene assemblages are Cytilus sericeus and Byrrhus fasciatus. There are also "typical Holocene" weevil species such as Grypus equiseti.
Some of these differences between the early Holocene and Pleistocene beetle faunas, such as the appearance of wood-related taxa, are easy to explain by the northward shift in treeline following the Lateglacial Event ca 15,000-12,500 yr BP (Sher et al., 2005). Other changes, such as the sharp increase in rove beetle diversity, require more serious consideration. In our opinion, these changes may signify different types of biogeochemical processes in the Pleistocene than in the Holocene. In the tundra-steppe biome those processes generally resembled those found today in steppe regions, where there are relatively small and unstable amounts of soil phytomass, quickly decomposed under relatively high summer temperatures in a highly oxidized environment. This seriously constrains the resource base for the litter-consuming beetles. In the early Holocene, the soil plant biomass sharply increased, due to an increase of shrub leaf litter instead of grasses, and the rates of its decomposition decreased, so comparatively large litter resources were formed. This hypothesis still needs to be tested by additional research, but in any case the sharp increase of diversity of the litter-associated insects seems very interesting.

Another interesting question is the appearance of some more thermophilic species in the early Holocene. The problem is that, according to our research (Alfimov et al., 2003; Sher et al., 2005), summer temperatures in the latest Pleistocene were rather high, a few degrees higher than today. We consider this problem in more detail, below (Section 5.4). It can be inferred that the increase in humidity in the early Holocene, in conjunction with persistently high summer temperatures, would favour the regional establishment of many relatively thermophilic, mesophilic insect species. Even more important was a very likely increase in winter precipitation and, hence, thickness of snow cover. This would have significantly improved the over-wintering conditions for many "thermophilic" insect species.

\subsection{Early Holocene assemblages and the problem of redeposition of insect fossils}

The occurrence of some typical Late Pleistocene (tundrasteppe) insects in the early Holocene assemblages is an important problem. Kiselyov $(1980,1981)$ was the first to take note of this, when he discovered that the early Holocene units from Ayon Island ( Fig. 1, site 16) and the adjacent northwest Chukotka coast, yielded insect assemblages containing up to $15-20 \%$ of typical Pleistocene tundra-steppe insects. Half or more of them belonged to Morychus viridis. The number of individuals of true steppe species, such as the ground beetles Harpalus pusillus and Cymindis arctica, the leaf beetle Chaetocnema costulata, and the weevils Stephanocleonus eruditus and S. foveifrons, varied from single individuals to $2-3 \%$ of the whole assemblage. Three samples from Ayon Island came from a unit with conventional radiocarbon ages between 8500 and $7700 \mathrm{yr}$ BP (Kiselyov, 1995). Another early Holocene 
sample came from the "Primorskiy" coastal section dated between 8900 and $7500 \mathrm{yr}$ BP. Interestingly, these assemblages also had very high percentages of true taiga species (up to $25 \%$ ); this was what distinguished them from the Pleistocene faunas. Kiselyov's conclusion was that the steppe species, and, hence, the relic tundra-steppe communities, survived into the early Holocene in this region. That deduction, if true, has important inferences for both the regional early Holocene environment, and for the ecology of the species in question.

We have observed a similar phenomenon in the early Holocene assemblages from the Laptev Sea area, as discussed above. Practically all of these assemblages contain fossils of Morychus viridis, ranging from single individuals up to $5-16 \%$ of the whole assemblage. We have also found the remains of Stephanocleonus eruditus, Troglocollops arcticus, Notiophilus aquaticus, Galeruca interrupta circumdata and Aphodius sp. in early Holocene assemblages. These occurrences beg the question of whether such species were true members of the early Holocene fauna, or whether their fossils were reworked from the underlying Pleistocene units or surrounding exposures of the latter.

The problem of reworked insect fossils has been considered by many experts. Traditionally, it was believed that the Quaternary fossil insects do not survive long transportation and redeposition because of the low durability of chitinous remains (Kiselyov, 1987), with the exception of transportation of insect fossils inside peat balls (Morlan and Matthews, 1983) or sediment fragments (Nazarov, 1984). The fossils of many insect species are indeed too fragile to endure transportation with rough clastic sediment, and in this case they would be either destroyed completely, or reduced to a very poor condition (fragmented, abraded, etc.). This, however, only holds true for rather coarse sediments found in fluvial, glacial and other kinds of active sedimentary environments. In less dynamic environments, such as slope wash, or slow reworking of fine-grained sediment by a meandering river, the fossils may retain their original state of preservation, even after reworking (see examples below).

The problem of redeposition of insect fossils has occupied the attention of one of us (SK) for many years of research in northeastern Siberia, and many interesting taphonomic observations have been made (Kuzmina, 2001). However, this is the first time that this issue has been discussed in our publications. At all of our fossil study sites, we collected modern insects by the traditional entomological methods. In addition, we took samples of subfossil insects from modern depositional environments, such as accumulations of plant detritus (flotsam) along the river banks and lake shores. These samples were processed in the same way as our fossil samples. Four of these samples are illustrated in the table in the on-line version of this article. These are representative of a much larger body of unpublished data we have collected.

Comparing these subfossil assemblages with the modern insect fauna from the same area, SK discovered a very interesting and unexpected pattern. The composition of subfossil assemblages from modern sediments (which have the potential to become fossil assemblages in future) was different from the living insect fauna, in that they include the remains of species not currently known in this area, but which were rather abundant in near-by exposures of Pleistocene deposits. This was especially evident in the cases when the river flotsam was collected on a bar a few hundred meters downstream from a Pleistocene bluff.

For example, the subfossil samples K-01 and K-02 (see table in the on-line version of this article) were obtained at the Keremesit River in the Yana-Indigirka Lowland (Fig. 1, site 5). The site is in the typical tundra subzone, and our modern insect collection reflects the local environment quite adequately. The fossil samples, however, show the presence of some steppe and meadow-steppe species, and Morychus viridis remains are very abundant. Since we did not find these "exotic" species in the modern fauna, nor did we find any suitable habitats, we infer that a considerable percentage of specimens in the flotsam assemblage came from the Pleistocene bluff immediately upstream.

Such inferences are also backed by direct observations. For instance, at the coastal cliff on the Bolshoy Lyakhovsky Island, one of the Pleistocene units exposed in the cliff was very rich in insect fossils. On a still, warm, sunny day, we observed these frozen sediments thawing, and their blocks falling down to the beach. They were quickly and gently rinsed by sea water, and that resulted in a very high concentration of Pleistocene insect fossils of good preservation on the modern beach.

On Bykovsky Peninsula, almost 600 insect remains have been collected from the present-day flotsam of a small lake, called "Mammoth's Eye" (see table in the on-line version of this article, sample Byk-B30). This sample contained 7\% Morychus viridis fossils $(\mathrm{MNI}=26)$, and even several fossils of the steppe weevil Stephanocleonus fossulatus. Although no open exposures were observed around the lake, both species most probably came from Pleistocene sediments of the surrounding hills. There are no suitable habitats for these beetles in the vicinity. On Bolshoy Lyakhovsky Island, we sampled the present-day flotsam of the Zimovye River, and also found Morychus viridis in this sample (L0-B0, see table in the on-line version of this article). With few exceptions, however, both subfossil assemblages generally reflect the modern environment quite adequately, i.e., they are basically modern assemblages.

Of course, all such accumulations of modern chitin along the river banks and sea or lake shores, enriched with Pleistocene beetle remains, would not necessarily become "fossil" in the geological sense. It is very likely that they will be reworked many times before final deposition. This would cause chitinous fossils to be damaged, especially the Pleistocene remains, because they are less durable than modern exosleketons. However, the possibility of their preservation as redeposited fossils still exists, and we believe that some of our Holocene samples confirm this. 
Two circumstances should be taken into account when considering the problem of redeposition in our particular region. The first is the ubiquitous permafrost, which facilitates excellent preservation of insect chitin in frozen sediments. These frozen fossils can be almost as intact as in modern specimens. The second is the prevailing fine-grain composition of sediments in the region (mostly silt and fine sand). Because of this, the insect fossils would be less damaged during redeposition.

The state of preservation of the insect fossils after reworking strongly depends on their exoskeletal anatomy. For instance, the steppe weevil Stephanocleonus eruditus and its relatives have very hard, robust exoskeletons, quite resistant to damage. However, other tundra-steppe species, such as Galeruca interrupta circumdata and Troglocollops arcticus, have softer exoskeletons, and their state of preservation is poor even in primary Pleistocene deposits. Thus, the possibility of their redeposition seems quite unlikely.

A more complicated problem concerns the possible redeposition of Morychus viridis remains. Exoskeletons of this species are of medium strength. M. viridis is the most abundant species in our Pleistocene assemblages, and, hence, its chances of redeposition are higher than for less common species of similar durability. Quite a number of M. viridis fossils have been encountered in most Holocene assemblages, both early and late. In some samples they are quite abundant (see table in the on-line version of this article). Most fossils of this species from Holocene sediments are of poor preservation, but well-preserved specimens occur among them. Although at present $M$. viridis is most common and abundant in cold steppe biotopes further south (Berman et al., 2001), it can be found in relict steppe habitats within tundra zone, e.g. in western Chukotka and on Wrangel Island. Taking into account all these considerations, we must admit that the early Holocene assemblages may include both redeposited and contemporary fossils of $M$. viridis. As to the late Holocene, especially on Bolshoy Lyakhovsky Island, where $M$. viridis fossils are quite abundant (low river terrace) they may all be redeposited, since this species is hardly ecologically compatible with the arctic tundra composition of the assemblage.

Thus, the phenomenon of redeposition of insect fossils in permafrost areas does exist and should not be dismissed, although this complicates the interpretation of insect assemblages. Each particular case requires special consideration of geological conditions, preservational character, etc. As our experiences show, such redeposition is more common in fluvial sediments, especially in basal horizons of low terraces, eroding Pleistocene sediments. We observed such a case on the Alazeya River (Fig. 1, site 4), where we studied the insect assemblages from the first terrace section (Kuzmina, 1989, 2001. The peat lens in the lower part of the section was dated to $8400 \pm 250 \mathrm{yr}$ BP (Rybakova and Tshernyshova, 1979). In the basal unit of the terrace section (Fig. 9), typical tundra-steppe species formed almost $50 \%$ of the insect assemblage (sample A1-203-1, see table in the on-line version of this article), but their number sharply decreased higher up the section. As the Alazeya is a slow, meandering river flowing through a plain, and the sediments are fine-grained, this might be a result of the alluvial origin of the section, and of the reworking of fossils from the nearest Pleistocene sections.

A similar example is described above (Section 4) for the low terrace of the Zimovye River on Bolshoy Lyakhovsky Island. The fossil assemblages contain a notable number of "exotic" species which currently do not live on the island, including Morychus viridis and the true steppe weevils Stephanocleonus eruditus and S. fossulatus. Taken as a whole, the fauna gave the impression of being a mixture of Holocene and Pleistocene assemblages, so in this case we suspect an important input of Pleistocene fossils from the sediments eroded by the river.

Attempting to understand the degree to which this input could distort the composition of the Holocene insect assemblages, we sampled the present-day alluvium of the Zimovye River. The sample (L0-B0, see table in the on-line version of this article) also includes species that do not live here today (Morychus viridis, Sitona borealis, Hypera ornata) and are evidently redeposited from older deposits. In general, however, the modern sample, dominated by tundra mesophiles and arctic tundra species, seems to more adequately represent the modern environment. In the late Holocene assemblages, arctic tundra beetles have a much lower percentage, while southern tundra species are more common. That leads us to conclude that the late Holocene environment was probably a little less severe than the present.

It seems that the probability of "contamination" of the Holocene assemblages with Pleistocene fossils is lower in the alass sections than in fluvial terraces, but cannot be completely excluded. The early Holocene assemblages from the alass sections on Bykovsky Peninsula and the Lena Delta never contain such high percentage of "exotic" species as are found in the fluvial samples, discussed above. However, there are $16 \%$ of Morychus viridis fossils in the lower sample from the alass section LL-17 on Bolshoy Lyakhovsky Island.

The best evidence of the bona fide presence of steppe species in the early Holocene (at least in the Lena Delta) was seen in the assemblages obtained from the sediments in "pockets" on top of the Ice Complex. As discussed above, these sediments were formed in small ponds inside lowcentre polygons, without active erosion of the underlying Pleistocene sediments. Theoretically, some fossils could get into the "pocket" from the thawing Pleistocene matrix, but that seems much less likely than in the alass and fluvial environments. The absence of redeposition in the "pockets" is supported by the following observations. The early Holocene "pockets" on the top of Mamontovy Khayata and Kurungnakh sections are inserted into the sediments of different age, and with very different insect faunas. In the first section, the uppermost Ice Complex sediments contain 
up to $73 \%$ of xerophilic insects, including $M$. viridis $(68 \%)$ and true steppe species (Sher et al., 2005). In the second section the assemblage consists mostly of arctic tundra insects, and M. viridis is not found. Nevertheless, both "pocket" assemblages are more similar in composition to each other than to the underlying Pleistocene matrix, and both include single fossils of relatively thermophilic xerophiles.

Thus, redeposition of Pleistocene insects into younger sediments exists and presents a serious problem. In fact, the problem can be solved quite easily by direct AMS dating of steppe species fossils from the Holocene sites, but this remains to be done. However, not all occurrences of "exotic" species in the Holocene can be explained by their redeposition.

A stronger case for the survival of tundra-steppe species in the early Holocene can be made on the basis of our conclusions about higher-than-present summer temperatures at that time. This conclusion is based not only on the presence of tundra-steppe species, but also on the presence of more thermophilic species in various ecological groups, sometimes very rarely or never encountered in the late Pleistocene. Thus, the survival of some tundra-steppe insects into the early Holocene is only one of factors that distinguishes the early Holocene faunas from the modern faunas. The former faunas have no modern analogue. Many of tundra-steppe species survived into the present time in northeastern Siberia, though their ranges have decreased dramatically. They persist in relatively small relict habitats surrounded by modern, often quite mesic, communities (Berman et al., 2001). In many cases their survival is supported by a specific type of local environment - the best example is Wrangel Island. Such relict habitats could have been somewhat more common in the early Holocene, as evidenced by our data, as well as by Kiselyov's sites on the Ayon Island and Chukotka.

\subsection{Insect assemblages and early Holocene environments in northeastern Siberia}

Independent evidence, mostly from palaeobotany and radiocarbon assay, may help us to understand the changes in the insect fauna at the Pleistocene/Holocene boundary and during the early Holocene. A large amount of paleobotanical evidence indicates the significant northern advance of shrubs and trees at this time. All pollen spectra from the early Holocene deposits of the vast territory from the Lena Delta and the New Siberian Islands, throughout the Yakutian Coastal Lowlands to Chukotka, and on Wrangel Island, show a sharp increase in arboreal pollen (Lozhkin, 1976; Boyarskaya and Kaplina, 1979; Kaplina and Lozhkin, 1979, 1982; Makeyev et al., 1989, 2003; Anderson and Lozhkin, 2002). This territory also has an extensive record of dated fossils of larch, tree birch and tall shrub alder, found north of the limit of their modern distribution (Kremenetski et al., 1996; MacDonald et al., 2000).
Radiocarbon evidence comes mainly from the sampling of thick autochthonous peat layers that fill the innumerable thermokarst kettles (alasses) and of lower river terraces. Most of the ${ }^{14} \mathrm{C}$ dates fall in the interval from $8900-7000 \mathrm{yr}$ BP (Kaplina and Lozhkin, 1979), Most alass peat units, however, are separated from the underlying Pleistocene deposits with a time gap (cf. Section 3.2.1), so they could not provide a continuous record of the Pleistocene/ Holocene transition. For example, on the Bykovsky Peninsula, no pollen samples have been obtained within the range of $12,000-8000 \mathrm{yr} \mathrm{BP}$, only a few dates fall within $8000-7000 \mathrm{yr}$ BP, and most dates are younger than $3000 \mathrm{yr}$ BP (Andreev et al., 2002). It was also not possible to trace the transition in the cores from Nikolay Lake in the northwestern Lena Delta (Fig. 1, site 23; Andreev et al., 2004b). The lack of continuous record is also true for our fossil insect sites in the Laptev Sea area.

There is only site in the vast region of the Siberian Arctic where the Pleistocene/Holocene transition has a known, continuous record; this site is close to our study area. This record comes from a 368-cm long lake core taken from the Dolgoe Ozero (Long Lake) (Fig. 1, site 24), situated on the $25-\mathrm{m}$ terrace of the Lena River, about $40-50 \mathrm{~km}$ south of the Lena Delta (Pisaric et al., 2001; Porinchu and Cwynar, 2002). The core has a good sequence of eight AMS dates ranging from 12,300 to $1,600 \mathrm{yr} \mathrm{BP}$, and has yielded pollen and stomate records. In addition, about 15 wood samples have been dated from old tree stumps, collected in the nowtreeless area of the lake from the flood-plain terraces and the tundra surface. The location of the site is a few $\mathrm{km}$ north of the modern forest-tundra boundary. The northernmost isolated stand of larch in the Lena valley is just $1 \mathrm{~km}$ south of the lake. This fact is very important for the interpretation of the site's fossil record, as it actually marks the present-day treeline.

The Dolgoe Ozero pollen record shows the dominance of grass-herb vegetation until about $12,500-12,200 \mathrm{yr}$ BP. That correlates very well with the latest tundra-steppe insect and pollen assemblages in the Bykovsky Ice Complex section (Sher et al., 2005). The first appearance of birch shrub tundra around the lake occurred between 12,200 and $11,000 \mathrm{yr}$ BP. Both this event and the subsequent short recovery of grass-herb, or tundra-steppe vegetation $(11,000-10,000 \mathrm{yr} \mathrm{BP})$, which Pisaric et al. (2001) suggest to be a possible correlative of the Younger Dryas event, are not recorded on the Bykovsky Peninsula or elsewhere in the study area. This tundra-steppe event with abundant wormwood (Artemisia) could potentially have facilitated the survival of some xerophilic insects into the next environmental stage.

The most dramatic change in the Dolgoe Ozero record occurs at 10,000 $\mathrm{yr}$ BP, when the grass and herb pollen almost disappears, and shrub alder becomes the dominant pollen type, followed by shrub birch (Pisaric et al., 2001). In the chironomid record of the same core, the period between 10,000 and $8300 \mathrm{yr} \mathrm{BP}$ is remarkable for the highest abundance of warm-water taxa and the complete 
disappearance of stenothermic cold-water species (Porinchu and Cwynar, 2002). Even much further north, in the Nikolay Lake record, which covers only the later part of this interval, the pollen spectra dated from ca 9000 to ca $8200 \mathrm{yr}$ BP are dominated by shrub alder $(30-40 \%)$ and shrub birch (10-25\%), with a notable percentage (5-15\%) of tree birch pollen (Betula sect. Albae) (Andreev et al., 2004b). The chironomid record of the same time period in Nikolay Lake shows the highest abundance of strongly warm-adapted taxa (some of them currently live in July water temperatures greater than $14^{\circ} \mathrm{C}$ ) and the absence of strongly cold-adapted species. The quantitative climate reconstructions based on palynology indicate that the summer during this period was warmer and drier than at Nikolay Lake today (e.g., mean July temperature was $1-2^{\circ}$ higher) (Andreev et al., 2004b).

The combination of pollen and chironomid evidence from the Dolgoe Ozero and Nikolay Lake cores indicates that the period between 10,000 and ca $8500-8200 \mathrm{yr}$ BP can be considered the Holocene thermal maximum in the Lena Delta area. The appearance of larch around Dolgoe Ozero was, however, delayed until the end of this period. Larch definitely reached the lake area at $8500 \mathrm{yr} \mathrm{BP}$, and the treeline was north of Dolgoe Ozero until $3500 \mathrm{yr}$ BP, as clearly demonstrated by the stomate record and the dating of larch stumps (Pisaric et al., 2001). Interestingly, the chironomid record in the same lake after $8500 \mathrm{yr}$ BP indicates cooling, rather than warming. A sharp increase in the deposition of cool-water midges at $8300 \mathrm{yr}$ BP may suggest the beginning of climatic deterioration at that time (Porinchu and Cwynar, 2002). Moreover, a similar, but even more pronounced change is observed in the chironomid record of the Nikolay Lake, where the most coldadapted taxa increase dramatically at the same time. Andreev et al. (2004b) explain this by invoking "the onset of colder, more maritime summer conditions" related to the sea level rise. Shrub alder and birch pollen percentages decline slightly in the Nikolay Lake core after $8000 \mathrm{yr}$ BP, but remain high enough to infer the presence of these shrubs around the lake until at least $7000 \mathrm{yr} \mathrm{BP}$, or possibly as late as $4500 \mathrm{yr}$ BP (Andreev et al., 2004b).

Thus, during the early Holocene (10,000-7000 yr BP) the area of the present Lena Delta had shrub tundra vegetation, possibly with some trees, such as larch (at least, in the south) and tree birch. The evidence from the lake cores is strongly supported by the dated finds of plant remains in the Lena Delta. On Kurungnakh Island (site 2, Fig. 1) the presence of tree birch at $8620 \mathrm{yr}$ BP and shrub alder at $8300 \mathrm{yr}$ BP is demonstrated by a dated wood sample (see Section 3.2.1). Interestingly, the same percentage of Betula sec. Albae pollen (5-15\%) is found within the interval of $9000-8000 \mathrm{yr}$ BP in the lake cores, both to the south (Dolgoe Ozero) and to the north (Nikolay Lake) of the macrofossil find. This may indicate that scattered birch trees were widely distributed in the whole Lena Delta area at that time. On Bykovsky Peninsula, unidentified wood samples from a layer rich with birch, shrub alder and larch remains were dated between 9500 and $9100 \mathrm{yr}$ BP. A perfectly preserved body of a moose (Alces alces L.) recently thawed from permafrost, was found at the extension of the Mamontovy Khayata cliff and dated to $8080 \pm 120$ yr BP (GIN-11727) (Sher et al., 2002a, b). The find was accompanied by abundant wood remains of tall shrubs (more than $2 \mathrm{~m}$ high), identified by V.R. Filin as willow (possibly, alder was also present). This wood comes from the top layer of the cliff, overlying the Late Pleistocene Ice Complex sediments above the moose carcass, so we assume that the moose body was originally buried there, and slid down when thawed. Such shrubs do not grow in the area today.

The widespread distribution of shrub alder on the New Siberian Islands (where it does not grow today) is a striking feature of the early Holocene vegetation. On Bolshoy Lyakhovsky Island, we encountered shrub alder remains in practically every early Holocene section, sometimes in an excellent state of preservation, with thin branches and buds. Abundant remains of shrub alder were found in the lower part of the alass LL-17 section. The wood bark from here yielded the age of $8020 \mathrm{yr}$ BP (cf. Section 3.2.1.). Earlier, shrub alder wood from the same region was dated at $9220 \pm 175 \mathrm{yr}$ BP (PI-215, Kaplina and Lozhkin, 1982). On the Kotelny Island, in the Balyktakh R. basin $\left(75.45^{\circ} \mathrm{N}\right.$, $139.1^{\circ} \mathrm{E}$ ), trunks and roots of shrub alder up to $8-9 \mathrm{~cm}$ in diameter were observed in many alass peat layers and the first terrace sediments (Makeyev et al., 1989). According to these authors, the radiocarbon ages of the peat layers with the remains of large shrubs (alder, willow, and birch) fall between $10,100 \pm 250$ (LU-1684) and $9080 \pm 80 \mathrm{yr}$ BP (LU-1467).

Around the same time, when larch appeared in the Lena valley near Dolgoe Ozero, or even slightly earlier, $8980 \pm 100 \mathrm{yr}$ BP (MAG-642) it grew at the present shoreline east of the Dmitry Laptev Strait $\left(72.16^{\circ} \mathrm{N}\right.$, $\left.146.83^{\circ} \mathrm{E}\right)$ and $7744 \pm 62 \mathrm{yr}$ BP (IGAN-1517) east of Tiksi $\left(71.5^{\circ} \mathrm{N}, 128.93^{\circ} \mathrm{E}\right)($ Kremenetski et al., 1996). Larch could even potentially have spread a little further north on the shelf land, but it is not known on Bolshoy Lyakhovsky and other islands.

In the early Holocene, tree birch was distributed as far north as larch or even further. Numerous early Holocene pollen spectra contain notable, though not very high, amounts of Betula sect. Albae pollen. The northernmost dated occurrences of tree birch wood are on the Laptev Sea coast. Wood samples from Van'kina Bay $\left(72.25^{\circ} \mathrm{N}\right.$, $140.25^{\circ} \mathrm{E}$ ) yielded an age of $8950 \pm 100 \mathrm{yr}$ BP (MGU-230, Kaplina and Lozhkin, 1979). Birch wood from the EastSiberian Sea coast at the mouth of the Bolshaya Kuropatochya River $\left(71.07^{\circ} \mathrm{N}, 156.17^{\circ} \mathrm{E}\right.$, Fig. 1) was dated as $9315 \pm 150 \mathrm{yr}$ BP (MAG-123, Kaplina and Lozhkin, 1979). Tree birch samples of early Holocene age have also been found in the lower courses of the Olenyok, Lena, Indigirka, Kolyma, and Rauchua Rivers and on the islands in Chaun Bay, Chukotka (MacDonald et al., 2000). There are also some unverified indications of much more 
extensive distribution of tree birch in the early Holocene. Kaplina (1981) refers to some earlier evidence that birch logs with well-preserved white bark were found together with abundant shrub remains in the alass sections on the Kotelny Island - the northernmost large island of the archipelago $\left(75-76^{\circ} \mathrm{N}\right)$. Assuming that most alasses were formed in the early Holocene, Kaplina concludes that tree birch existed on the New Siberian Islands during the time interval from 9.3 to $8.5 \mathrm{kyr}$ (Kaplina and Chekhovskiy, 1987). In addition, Makeyev et al. (1989), describing the early Holocene vegetation of the Kotelny Island, mention tree logs up to $15-20 \mathrm{~cm}$ in diameter, found in the center of the island. If any trees really grew there in the Holocene, it could only have been birch. However, during the recent work on many alass sections on New Siberian Islands no tree birch logs were found (V. Tumskoy, pers. comm., 2005). Thus, the mentioned dated find of tree birch at the Van'kina Bay remains its northernmost documented occurrence.

The evidence discussed above shows that in the early Holocene tall shrubs and perhaps even some trees occurred over almost the whole area of modern tundra of northeastern Siberia. In the eastern sector of the Laptev Sea area, the northern advance of tall shrub alder was as much as $500-700 \mathrm{~km}$. In modern terms this vegetation would be classified as forest-tundra, rather than shrub tundra.

The most peculiar character of all the early Holocene insect assemblages studied in this region (10 samples) is that they have some thermophilic species, currently known from taiga and forest-tundra south of the study sites, including those indicating the presence of trees and shrubs in the area. However, none of them can actually be classified as a typical forest-tundra assemblage. They are strongly dominated by mesophilic tundra insects $(50-70 \%$ in most samples, average 53\%). The percentage of all "forest-tundra" species (including "shrub", "meadow" and "taiga" groups) usually varies from $5 \%$ to $15 \%$ (average $8.7 \%$ ), and in one sample only (BKh-02-B1) it reaches $22 \%$, while in two samples it is less than $2 \%$. The "shrub" group on the average has a little higher percentage than the "taiga" (4.3 and 3.8\% respectively), but this relationship varies from sample to sample. Very remarkably, the early Holocene assemblages include practically no obligate treeassociated insects such as Cerambycidae, Buprestidae, Scolytidae, some weevils relying on coniferous trees (Hylobius piceus DeG., Pissodes spp,), quite common in modern larch taiga. The only exception is a single fossil of the bark beetle Polygraphus sp. (Scolytidae) in sample BKh-B4, and single fossils of the carpenter ant, Camponotus herculeanus, which nests in mostly dead tree logs (including driftwood) and the ground beetle Dromius quadraticollis (in sample MKh-01-02) living under tree bark.

At first glance, the early Holocene insect assemblages in the Laptev Sea tundra area indicate a shift towards warmer and more humid climate. This is especially evident for Bolshoy Lyakhovsky Island, where the fossil fauna (LL17-
B20) includes some tundra forms that would hardly be able to survive on the island today. Correspondingly, more southern sites in the Lena Delta include several species of ground beetles, rove and carrion beetles that currently live only further south, in forest-tundra and taiga. However, most assemblages have too low percentages of taiga and shrub-associated beetles to adequately correspond to the modern forest-tundra fauna. Finally, they all include small number of species of the steppe group (sensu lato, including hemicryophytic steppe, thermophytic steppe, and meadowsteppe, see Section 2), which are uncommon or absent in modern forest-tundra.

Similar features of the early Holocene insect assemblages have been noticed in the regions further east, along the Khroma, Alazeya and Kolyma Rivers (Kiselyov, 1981, 1995; Kuzmina, 1987, 1989, 2001; Kuzmina and Kolesnikov, 2000). Kiselyov (Boyarskaya and Kiselyov, 1981) mentioned the insufficient representation of the forest insects in the early Holocene assemblages, accompanied by arboreal-dominated pollen spectra (trees and shrubs) in the Kolyma, Indigirka and Chukotka regions. The only exclusion is the early Holocene samples from Ayon Island, where the percentage of forest-tundra species is as high as 20-29\%, including some dendrophilous species (Kiselyov, 1980, 1995). The presence of relict tundra-steppe species in the early Holocene assemblages of Ayon Island and the Primorsky locality (Chukotka) was discussed above. Fossils of such species as Morychus viridis, Stephanocleonus spp. and Coniocleonus spp., have been also found in the Holocene samples from the Alazeya River (Fig. 1, site 4, Kuzmina, 1989, 2001) and Medvezhyi Islands (Fig. 1, site 11, Kuzmina and Kolesnikov, 2000). Thus, the main features of the early Holocene insect assemblages in the Laptev Sea region - the tundra background, the "underdeveloped" forest component, and the presence of steppe (sensu lato) species have been described for the faunas of this period in other areas of the northern coast of northeastern Siberia. Kiselyov (1980) suggested that the environment at least on the West Chukotka was not completely similar to the present, and called it "foresttundra-steppe".

Thus, the early Holocene insect assemblages were different from modern faunas of the tundra and the forest-tundra, and, hence, do not agree with vegetation reconstructions that imply a simple shift of modern vegetation to the north. The problem is whether the early Holocene vegetation of modern tundra areas was completely similar to any type observed now in the region.

Some evidence suggests that it was not. For example, Rybakova and Tshernyshova (1979) interpreted the early Holocene vegetation $(8400 \pm 250 \mathrm{yr}$ BP, PI-268) in the Kolyma Lowland (Alazeya River, Fig. 1, Site 4) as "birch forest-tundra" because of the much higher content of tree birch pollen in the spectra as compared with modern surface samples from forest-tundra. Further east, in modern southern (shrub) tundra by the Bolshaya Kuropatochya River (Fig. 1, site 21), tree birch wood from alass 
sections was dated as $8560 \pm 60 \mathrm{yr}$ BP (MAG-253) and $8650 \pm 650$ yr BP (MAG-237) (Anderson and Lozhkin, 2002). These authors interpret the vegetation of that time as birch forest-tundra. Interestingly, some pollen spectra of the layers with tree birch show rather high percentage of Asteraceae and Artemisia pollen, indicating the presence of dry and relatively well-heated habitats, probably, on southfacing slopes.

A closer look at the modern and past distribution of the principal trees and shrubs of the region might help elucidate the problem. At present, larch (Larix dahurica) is the main component tree of the forests in northeastern Siberia and the species that forms the northern tree line, as well as the boundary between forest-tundra and tundra. The northernmost occurrences of larch trees can be usually found about $200 \mathrm{~km}$ south of the Arctic Ocean. However, along some major river valleys larch can grow as close as $50-100 \mathrm{~km}$ to the coast. No other coniferous trees grow in northeastern Siberia, at least north of the Magadan area and east of the Lena River, except the dwarf pine, Pinus pumila. Tree birch species (Betula pubescens, B. pendula) are rarer, and occur as secondary trees in larch taiga in some areas; their northern limit never reaches that of larch. In contrast, shrub alder (Duschekia fruticosa), now common in the taiga zone, is distributed a little further north than larch, into the southern (shrub) tundra, but only for the first few tens of kilometres. In the early Holocene, larch, tree birch and shrub alder all advanced northward, but the respective positions of their northern limits seem to be different than they are today. While the minimum advance of larch can be estimated in $50-200 \mathrm{~km}$, tree birch grew at least $300-600 \mathrm{~km}$ and shrub alder grew $500-700 \mathrm{~km}$ north of its present limit.

The summary of the botanical and radiocarbon evidence allows us to infer that the early Holocene vegetation of the modern coastal area and the now-inundated shelf was not similar to any of the vegetation types currently present in northeastern Siberia. It may have been open tree-birch woodland, with birch, alder and willow shrubs and isolated groves of larch, the latter mostly in the south. This landscape presumably had more widespread and more diverse tundra communities than are found in modern forest tundra or larch forest, including grass/herb-dominated tundra communities. In different kinds of modern larch forest in northeastern Siberia, the lower stratum of the plant community is formed by dwarf shrubs, mosses and lichens. Grass/herb cover is usually not developed, except cotton-grass and mesophilic sedge communities in wet habitats, similar to the tundra ones. We further suppose that although mesic tundra habitats were more abundant, some better-drained and warmer sites may have hosted more xeric, grass/herb communities. This means that the early Holocene vegetation comprised a more diverse mosaic of communities, in this way resembling the Late Pleistocene vegetation more than the modern vegetation. Such a reconstruction would explain the unusual composition of the early Holocene insect assemblages, with their dominance of mesic tundra species, combined with some steppe forms, and a number of thermophilic (taiga-zone) species, but lacking in tree-associated insects.

\subsection{Holocene climatic and environmental trends and the history of insect fauna in northeastern Siberia}

As follows from the previous sections, all kinds of evidence, including fossil insects, indicate that the early Holocene environment in northeastern Siberia existed under a climate that was warmer than present. The published quantitative estimates are based on different proxy sources. Kaplina and Chekhovskiy (1987) calculated the temperatures necessary to trigger the active thermokarst on the Coastal Lowland of Yakutia around the Pleistocene/Holocene boundary. According to them, mean annual air temperature must have been about $8-10{ }^{\circ} \mathrm{C}$ higher than present. They believed such a warming was mainly due to a summer temperature increase (as the total summer heat, according their calculations, had to double) plus some increase in winter precipitation (snow thickness). The corresponding values of mean July temperature would be $18-19^{\circ} \mathrm{C}$, which is $5-6^{\circ} \mathrm{C}$ higher than observed today in the areas of the Lowland, away from the sea coast.

For Kotelny Island, Makeyev et al. (1989) estimated that mean July temperatures were $5-6{ }^{\circ} \mathrm{C}$ higher than present (i.e., 7-9 ${ }^{\circ} \mathrm{C}$ ) between 10,000 and $9000 \mathrm{yr}$ BP and that the humidity was higher than today. The pollen-based climatic reconstruction for the optimal period of $9100-8200 \mathrm{yr}$ BP at Nikolay Lake suggests that mean July temperatures were $2{ }^{\circ} \mathrm{C}$ higher than present, with a subsequent cooling after 8100 yr BP (Andreev et al., 2004b).

As mentioned in Section 3.1., the present climate of all our study sites is strongly influenced by their proximity to the coast. The lake core sites at Dolgoe and Nikolay lakes are likewise close to the coast. According to Alfimov and Berman (2004), the direct climatic effect of the Arctic Ocean (in particular, the lowering of summer temperature) occurs at sites within $250-300 \mathrm{~km}$ of the coast. This means that the position of the shoreline is critical for understanding the Holocene climate.

In earlier work by one of us (Sher, 1997) it was suggested that by $9000-8000 \mathrm{yr}$ BP the sea already occupied the major part of the modern Laptev Sea, and, hence, could have seriously affected the early Holocene environment. However, recent extensive Russian-German coring of the bottom sediments in the Laptev Sea (14 sediment cores, 119 AMS ${ }^{14} \mathrm{C}$ dates on marine shells) (Bauch et al., 2001) produced serious corrections to our model. It has been shown that by $9100 \mathrm{yr}$ BP (9800 calibrated yr BP) the sea level was still at the $-43 \mathrm{~m}$ mark, and the major part of the Laptev shelf was still dry land (Fig. 12). By ca $8350{ }^{14} \mathrm{C}$ yr $\mathrm{BP}$ the sea intruded further into the Khatanga and Yana paleo-valleys, and inundated a large shelf plateau north of the recent Lena Delta, but a vast area of land was still present north of the modern shoreline, especially in the area between the Lena and Yana rivers and the New Siberian Archipelago. The latter was also all dry land at 


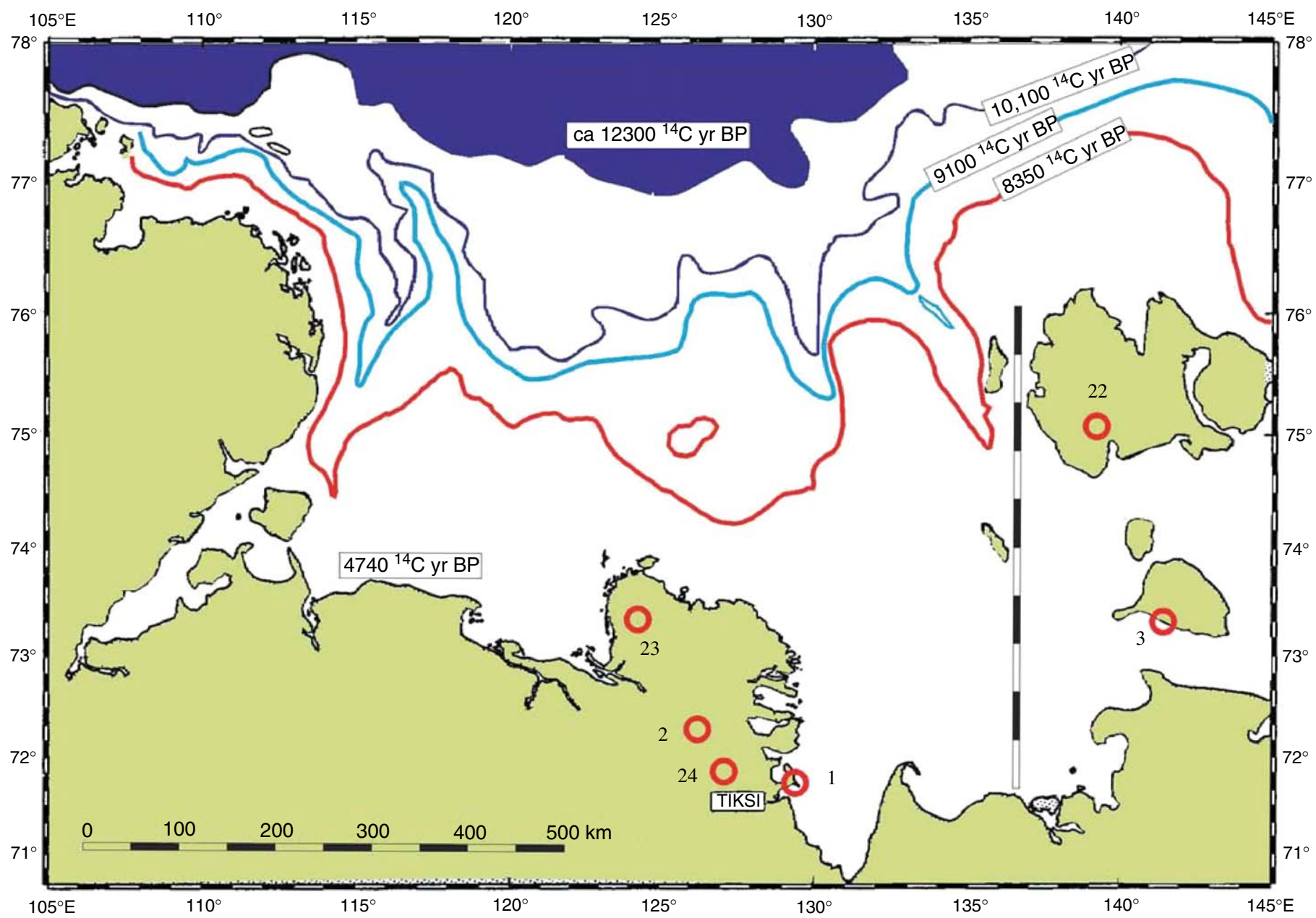

Fig. 12. Sea level on the Laptev Sea shelf during Holocene (after Bauch et al., 2001). The site numbers correspond to those in Fig. 1).

that time. As Fig. 12 shows, around 9000 yr BP all our sites were more than $400 \mathrm{~km}$ from the shoreline. Hence, the temperature distribution at the sites was not affected by proximity to the sea, and followed the normal latitudinal gradient of $0.4-0.5^{\circ} \mathrm{C}$ cooling per increasing $1^{\circ}$ of latitude (Alfimov and Berman (2004). The present mean July temperature at the weather stations, which are at the same latitude, but distant from the Arctic Ocean (Reference Book of Climate of the USSR, 1966-68) can be considered as approximate values for our sites, if they were unaffected by the proximity to the sea. Such an estimate allows us to assume that at $9000 \mathrm{yr} \mathrm{BP}$, the mean July temperature at $72^{\circ} \mathrm{N}$ (the south of the Lena Delta, the Kurungnakh Island and Bykovsky insect sites and Dolgoe Lake) would have been about $12^{\circ} \mathrm{C}$ (i.e., $3{ }^{\circ} \mathrm{C}$ higher than today on Kurungnakh and $5^{\circ} \mathrm{C}$ higher than on Bykovsky). If we remove the "sea effect" from the Bolshoy Lyakhovsky Island insect site and the Nikolay Lake $\left(73.3^{\circ} \mathrm{N}\right)$, we may infer that mean July temperatures at these sites were about $9{ }^{\circ} \mathrm{C}$, which is about $6^{\circ} \mathrm{C}$ higher than the coastal stations on Lyakhovsky show today, and about $4{ }^{\circ} \mathrm{C}$ higher than at Nikolay Lake (the present mean July temperature there is $5^{\circ} \mathrm{C}$ according to Andreev et al., 2004b).
This means that due to persistent low sea level in the early Holocene, the mean July temperatures at our sites would have been $3-6^{\circ} \mathrm{C}$ higher than today, even without any general climate warming. Such a level of July temperature would already be sufficient for the most thermophilic steppe species in our Holocene faunas, Stephanocleonus eruditus, to live in the south of the Lena Delta $\left(12{ }^{\circ} \mathrm{C}\right.$ is the currently observed July temperature minimum for this species, according to Alfimov et al., 2003). Such temperatures would have been high enough to allow Morychus viridis to exist at the Lyakhovsky site, provided the appropriate habitats were available.

Thus, neither the paleobotanical evidence, nor the fossil insect data require the assumption that mean summer temperatures in the early Holocene were higher than could be expected from the effects of distant shoreline position. However, according to Kaplina and Chekhovskiy (1987), such a raise in summer temperature could not trigger the mass thermokarst processes. These authors based their calculations on the present temperature conditions in the vast Coastal Lowland of Yakutia, including areas quite distant from the sea $(>250 \mathrm{~km})$, where the mean July temperature today is $12.5-13^{\circ} \mathrm{C}$. Unlike the coastal sites, the effect of the "distant sea" was minimal here. However, the 
rise in summer temperature that is necessary for thermokarst development is equally applicable to these areas (Kaplina and Chekhovskiy, 1987). This, in turn, indicates climate warming on a broad regional scale, not just local warming. We can thus conclude that the early Holocene rise in July temperature was very significant, especially at modern coastal sites, where the general warming was combined with the local "distant sea" effect. Such a conclusion, however, does not seem to go far enough in explaining the peculiar character of the early Holocene vegetation and insect fauna. Even during the Last Glacial Maximum, summer temperatures on Bykovsky Peninsula were higher than they are today, about $9-10{ }^{\circ} \mathrm{C}$ (Sher et al., 2002a, b; Alfimov and Berman, 2004). It should have been still higher $\left(>12{ }^{\circ} \mathrm{C}\right)$ during the Lateglacial Event, ca 15,000 to $12,500 \mathrm{yr}$ BP, the last period just before the Pleistocene/Holocene transition when steppe insects and plants were abundant there (Kienast et al., 2005; Sher et al., 2005). Thus, summer temperature in the early Holocene and the latest Pleistocene were not very much different from each other. Why then were the insect faunas and vegetation of those times are so dramatically different? The only possible answer is that they existed under very different climatic regimes.

Highly continental climate of the latest Pleistocene existed under prevailing anticyclonic conditions with minimal oceanic effect. Prior to $13,000-12,000 \mathrm{yr}$ BP the shelf land was apparently in direct contact with permanent pack ice, with almost no open water in summer (Dunaev and Pavlidis, 1990; Sher, 1997). It seems very likely, then, that open summer waters may have appeared during the early stages of sea level rise (12,000-10,000 yr BP). Besides the southward shift of the shoreline, climate warming, including an inevitable rise in temperature of the powerful river run-off into the Laptev Sea, had evidently made a major contribution to this phenomenon. If this hypothesis is correct, the appearance of cold open waters in summer changed the climatic situation towards a more cyclonic type, well before a significant part of the shelf land was inundated. This would bring increasing precipitation, and greater snow cover thickness in particular, which is so critical for thermokarst development (Kaplina and Chekhovskiy, 1987). Together with the general climate warming, these trends may have been important factors in triggering thermokarst activity during the PleistoceneHolocene transition. The extensive thermokarst resulted in the appearance of myriads of lakes on what was previously a mostly arid landscape. Even today, when many thermokarst lakes have been drained, the areal coverage of water (lake) surfaces in some areas of the Coastal Lowland can exceed $50 \%$. This means that when numerous lakes appeared, they became an additional and powerful source of moisture in the local climate. At the same time, the newborn lakes increased the areas of wetland in the landscape, thus facilitating a wider distribution of all kinds of hygrophylic insects, including mesic tundra inhabitants.

This concept reconstructs the early Holocene as a relatively short period in the past, when a significant climate warming, so far not overprinted by the approaching, but still distant, cold sea, coincided with a dramatic increase in available moisture. The combination of those two factors resulted in an enormous increase in plant biomass production. Even today, about 10,000 yrs later, the early Holocene plant remains that accumulated in numerous alass sections provide as much organic carbon input to the Laptev Sea (due to the coastal erosion) as all the great rivers draining the whole territory of Yakutia (Semiletov, 1999).

This scenario can explain the most peculiar features of the early Holocene insect fauna. The dominance of mesophilic tundra species may be related to the increased humidity and the abundance of mesic habitats around numerous thermokarst lakes. The corresponding increase in the snow cover thickness would allow the survival of many relatively "thermophilic" insect species that currently do not occur north of the taiga zone. Such a combination of ecological conditions and limiting factors cannot be observed in our region today. The early Holocene combination of relatively warm summers and milder winters with thicker snow cover was more favourable for shrubs and trees than for grassland. However, it did not allow the modern-type larch taiga or larch forest-tundra with their peculiar plant ground cover to spread into the high Arctic. Instead, it promoted open birch woodland with a mosaic of wetter and drier habitats. Small and scattered groves of trees can explain the rarity of dendrophagous insects. On the other hand, this new climatic situation did not prevent the survival of isolated patches of more xeric grass and herb communities on better drained sites. These patches may still have served as relic habitats for some Pleistocene insect species (to the extent allowed by high summer temperatures and thick snow cover). Interestingly, in our "top pocket" sample MKh99$3 \mathrm{aC}$, dated to $7790 \mathrm{yr} \mathrm{BP}$, in which we have not found any steppe insects due to the taphonomic bias (see above, Section 4), F. Kienast has found seeds of such steppe plants as Potentilla arenosa, P. stipularis, and Carex duriuscula (Kienast et al., 2005).

The retention of some steppe-like grassland habitats in the early Holocene may help us explain the survival of some Pleistocene grazing mammals into the Holocene times. Woolly mammoth survived in the north of the Taimyr Peninsula until $9670 \pm 60 \mathrm{yr} \mathrm{BP}$, but this was probably its last refuge on the Siberian mainland (Sulerzhitsky, 1995. Holocene mammoth remains have not yet been found on the lowlands surrounding the Laptev Sea, probably because the Taimyr Peninsula has more rocky and mountainous terrain, and it was not so greatly affected by thermokarst, as the Ice Complex was not so common there. The amazing survival of mammoth on Wrangel Island until $3700 \mathrm{yr} \mathrm{BP}$ is thought to be related to the existence of the relic tundrasteppe plant communities there (Vartanyan et al., 1993). Recently, it has been found that bison survived into the early Holocene in the Laptev Sea area (the Popigay River Basin) dated to $8860 \pm 40$ BP (MacPhee et al., 2002). But 
the most surprising is the survival of Pleistocene horse until the late Holocene. Currently, there are four ${ }^{14} \mathrm{C}$ dates known in the Laptev Sea area in the time range between 9000 and $2000 \mathrm{yr}$ BP (Sher et al., 2005), two of them come from the sites described in this paper. The horse bone dated to $4610 \pm 40 \mathrm{yr}$ BP was found on the beach at the MB site (Bykovsky Peninsula). An even younger record $(2200 \pm 50 \mathrm{yr}$ BP) of horse occurs near the Zimovye River mouth on Bolshoy Lyakhovsky Island; unfortunately, this sample has no precise geological context (Sher et al., 2005). Horse fossils are extremely abundant in the Pleistocene sediments; about $70{ }^{14} \mathrm{C}$ dates are known only from the Laptev Sea area. The Holocene finds are very rare, which may indicate that the surviving populations were very small and scattered.

Unfortunately, no middle Holocene insect assemblages are known from the Laptev Sea region. There are some indications (e.g. the Dolgoe and Nikolay Lake chironomid records) that summer temperatures started to decrease after 8000 yr BP (Porinchu and Cwynar, 2002; Andreev et al., 2004b). As we mentioned above (Section 3.2.4.), tall shrubs probably started to retreat from the High Arctic around $7500 \mathrm{yr}$ BP. About the same time (ca $7000 \mathrm{yr}$ BP) a sharp decline in total organic content is observed in the Nikolay Lake core (Andreev et al., 2004b). The cooling impact of the approaching sea was the most probable reason of this environmental change. After the sea level reached the isobath of $-25 \mathrm{~m}$, the transgression entered the shallowest part of the Laptev Sea, and the land was rapidly inundated (Bauch et al., 2001). By ca $4700 \mathrm{yr}$ BP the shoreline reached its modern position. A rough estimate shows that in the middle Holocene the shoreline was moving south by about $1 \mathrm{~km}$ every $10 \mathrm{yrs}$ - a catastrophic rate in the geological sense. The land configuration also had to change very rapidly, and that may explain some very short-term but sharp climatic changes observed in the middle Holocene part of the Nikolay Lake core (Andreev et al., 2004b).

According to various lines of evidence (MacDonald et al., 2000; Pisaric et al., 2001; Anderson and Lozhkin, 2002) the retreat of larch, birch and tall shrubs was finished, and the modern vegetation was essentially established, when shoreline acquired its modern outlines, i.e. between 4500 and $3500 \mathrm{yr}$ BP. The fossil insect assemblages of this time are also much more similar to the modern fauna than they were to the early Holocene faunas. A comparison of the 4000-3000-yr-old assemblages from the Bolshoy Lyakhovsky Island with those from the Central Lena Delta highlights the differences in the present environments of these respective sites. Hence, the late Holocene insect faunas seem more latitude-dependent than the early Holocene and Pleistocene assemblages. This is confirmed by many small single samples that we studied from various locations in northeastern Siberia, such as river terraces or young lake deposits. All of these assemblages were similar to modern faunas (Kiselyov, 1981; Kuzmina, 2001 and unpublished data). Still, for some late Holocene assemblages we cannot completely exclude the presence of some relatively thermophilic species, and, hence, a little more favourable conditions in some habitats. Although the number of thermophilic and steppe relicts notably decreased in the late Holocene assemblages, some of them could probably survive in small numbers under special habitat conditions. The best example is probably the late Holocene fauna of Ayon Island, with its steppe relicts (Kiselyov, 1980, 1995). The present occurrence of such species as Morychus viridis, Troglocollops arcticus, and some other cold steppe and meadow-steppe beetles on Wrangel Island makes such an assumption quite acceptable. Evidently, some plant and insect species that were very common in tundra-steppe biome could survive as relicts in certain restricted habitats, contrary to mammoths that could not survive the late Holocene (i.e., almost modern) conditions on Wrangel Island and eventually became extinct about 3700 yrs ago.

\section{Acknowledgements}

This research would not have been possible without the support of the Russian-German Program "The Laptev Sea System-2000", the Russian Foundation for Basic Research (RFBR project No. 04-04-48770), and the RussianGerman Otto Schmidt Laboratory for Polar and Marine Research. We thank all our Russian and German colleagues who helped us in the field work in this hardly accessible region, and particularly L. Schirrmeister for providing some unpublished radiocarbon dating results. Our special thanks go to S. Kiselyov, the pioneer of fossil insect studies in northeastern Siberia, for his kind permission to access his materials. The submitted version of the MS was very carefully read by two reviewers, S. Elias and $\mathrm{N}$. Whitehouse. We highly appreciate their hard work to improve the MS, their constructive criticism and very useful comments.

\section{Appendix A. Supplementary Materials}

The online version of this article contains additional supplementary data. Please visit doi:10.1016/j.quascirev.2006.01.013.

\section{References}

Alfimov, A.V., Berman, D.I., 2004. Distribution of thermophytic tundrasteppe and the climate of the Last Glacial Maximum in northeastern Asia. Earth Cryosphere 8 (4), 78-87 (in Russian).

Alfimov, A.V., Berman, D.I., Sher, A.V., 2003. Tundra-steppe insect assemblages and reconstruction of Late Pleistocene climate in the lower reaches of the Kolyma River. Zoologicheskiy Zhurnal 82 (2), 281-300 (in Russian).

Anderson, P.M., Lozhkin, A.V. (Eds.), 2002. Late Quaternary Vegetation and Climate of Siberia and Russian Far East (Palynological and Radiocarbon Database). NESC FEB RAS, Magadan, pp. 1-369.

Anderson, P.M., Lozhkin, A.V., Brubaker, L.B., 2002. Implications of a 24,000-yr palynological record for a younger dryas cooling and for 
boreal forest development in northeastern Siberia. Quaternary Research 57, 325-333.

Andreev, A.A., Schirrmeister, L., Siegert, Ch., Bobrov, A.A., Demske, D., Seiffert, D., ubberten, H.-W., 2002. Paleoenvironmental changes in Northeastern Siberia during the Late Quaternary-evidences from pollen records of the Bykovsky Peninsula. Polarforschung 70, 13-25.

Andreev, A.A., Grosse, G., Schirrmeister, L., Kuzmina, S.A., Novenko, E.Yu., Bobrov, A.A., Tarasov, P.E., Ilyashuk, B.P., Kuznetsova, T.V., Krbetschek, M., Meyer, H., Kunitsky, V., 2004a. Late Saalian and Eemian paleoenvironmental history of the Bol'shoy Lyakhovsky Island (Laptev Sea region, Arctic Siberia). Boreas 33, 319-348.

Andreev, A., Tarasov, P., Schwamborn, G., Ilyashuk, B., Ilyashuk, E., Bobrov, A., Klimanov, V., Rachold, V., Hubberten, H.-W., 2004b. Holocene paleoenvironmental records from Nikolay Lake, Lena River Delta, Arctic Russia. Palaeogeography, Palaeoclimatology, Palaeoecology 209 (1-4), 197-217.

Bauch, H.A., Mueller-Lupp, T., Taldenkova, E., Spielhagen, R.F., Kassens, H., Grootes, P.M., 2001. Chronology of the Holocene transgression at the North Siberian margin. Global and Planetary Change 31 (1-4), 125-139.

Berman, D.I., 1992. Ecology of the pill beetle Morychus viridis (Coleoptera, Byrrhidae) and reconstruction of the Pleistocene landscapes of the northeastern USSR. Chteniya pamyati A.I. Kyrentsova, 1-2. Vladivostok, c. 30-63 (in Russian).

Berman, D.I., Alfimov, A.V., Mazhitova, G.G., Grishkan, I.B., Yurtsev, B.A., 2001. Cold Steppe in Northeastern Asia. Institute of Biological Problems of the North, Magadan (pp. 1-183) (in Russian).

Boyarskaya, T.D., Kaplina, T.N., 1979. New data on vegetation development in Northern Yakutia during the Holocene, vol. 5. Vestnik Moskovskogo Universiteta, Geografiya (pp. 70-75) (in Russian).

Boyarskaya, T.D., Kiselyov, S.V., 1981. On some features in the history of the Holocene biogeocenoses in Northeastern Asia. In: Dinesman, L.G. (Ed.), Anthropogenic Factors in the Development of Modern Ecosystems. Nauka, Moscow, pp. 195-202 (in Russian).

Boyarskaya, T., Kiselyov, S., Kuzmina, S., 1983. Features of the Western Chukotka climate in the Late Pleistocene and Holocene. Past Climates of the Late Pleistocene and Holocene Moscow, pp. 151-154 (in Russian).

CAPE Project Members, 2001. Holocene paleoclimate data from the Arctic: testing models of global climate change. Quaternary Science Reviews 20, 1275-1287.

Coope, G.R., 1967. The value of Quaternary insect faunas in the interpretation of ancient ecology. In: Cushing, E.J., Wright, Jr., H.E. (Eds.), Quaternary Paleoecology (Proceedings of VII INQUA Congress, 7). Yale U.P., New Haven, pp. 359-380.

Coope, G.R., 1970. Climatic interpretations of Late Weichselian Coleoptera from the British Isles. Revue de Géographie Physique et de Geologie Dynamique 12, 149-155.

Dunaev, N.N., Pavlidis, Ju.A., 1990. A model of the Late Pleistocene glaciation of Eurasiatic Arctic shelf. In: Arctic Research: Advances and Prospects. Proceedings of the Conference of Arctic and Nordic Countries on Coordination of Research in the Arctic, Leningrad, 1988. Nauka, Moscow, pp. 70-72.

Elias, S.A., 1994. Quaternary Insects and Their Environments. Smithsonian Institution Press, Washington.

Grosse, G., Schirrmeister, L., Krbetschek, M., Schwamborn, G., Oezen, D., Kunitzky, V., Kuznetsova, T., Kuzmina, S., 2002. New data on Late Quaternary terrestrial permafrost deposits of the Laptev Sea Region by IR-OSL, Radiocarbon and U/Th age determination. International Conference "Climate Drivers of the North" (Kiel, May 8-11, 2002). Terra Nostra. Schriften der Alfred-Wegener-Stiftung, Berlin (pp. 46-47).

Kaplina, T.N., 1981. Late Cenozoic history of permafrost deposits in Northern Yakutia. In: Dubikov, G.I., Baulin, V.V. (Eds.), History of Development Of Permafrost Grounds in Eurasia. Nauka, Moscow, pp. 153-181 (in Russian).

Kaplina, T.N., Chekhovskiy, A.L., 1987. Reconstruction of paleogeographic conditions of the Holocene climatic optimum on the Coastal Lowlands of Yakutia. In: Pokhialaynen, V.P. (Ed.), Quaternary of Northern-east Asia. SVKNII DVO, Magadan, pp. 145-151 (in Russian).

Kaplina, T.N., Lozhkin, A.V., 1979. Age of alas deposits of the Coastal Lowland of Yakutia. Izvestiya Academii Nauk USSR. Seria Geologicheskaya, vol. 2. pp. 69-76 (in Russian).

Kaplina, T.N., Lozhkin, A.V., 1982. History of vegetation development in the Coastal Lowlands of Yakutia during the Holocene. In: Velichko, A.A. (Ed.), Environmental Development of USSR Territory during the Late Pleistocene and Holocene. Nauka, Moscow, pp. 207-220 (in Russian).

Khotinskiy, N.A., 1977. Northern Eurasia During the Holocene. Moscow, Nauka (in Russian).

Khotinskiy, N.A., 1984. Holocene climatic changes. In: Velichko, A.A., Wright, H.E., Barnosky, C.W. (Eds.), Late Quaternary Environments of the Soviet Union. The University of Minnesota Press, Longman, London, pp. 305-312.

Kienast, F., Schirrmeister, L., Siegert, Ch., Tarasov, P., 2005. Palaeobotanical evidence for warm summers in the East Siberian Arctic during the last cold stage. Quaternary Research 63 (3), 283-300.

Kiselyov, S.V., 1980. Outcrop of the Aion island. Entomofauna analysis. In: Kaplin, P.A. (Ed.), The Latest Deposits and Paleogeography of the Pleistocene in Chukotka. Nauka, Moscow, pp. 194-196 (in Russian).

Kiselyov, S.V., 1981. Late Cenozoic Coleoptera of North-East Siberia. Nauka, Moscow (in Russian).

Kiselyov, S.V., 1987. Paleoentomology method. In: Kaplin, P.A. (Ed.), Manual in the Latest Deposits Researches. MSU, Moscow, pp. 190-194 (in Russian).

Kiselyov, S.V., 1995. Northern Eurasia environment in the Pleistocene and Holocene (after Coleoptera insects researches). Thesis in Geology, Moscow, MSU (in Russian).

Kremenetski, K.V., MacDonald, G.M., Galabala, R.O., Lavrov, A.S., Chichagova, O.A., Pustovoitov, K.E., 1996. On the Holocene shifts of northern limits of some species of trees and shrubs. Botanicheskiy Zhurnal 4, 10-25 (in Russian).

Kryzhanovskij, O.L., Belousov, I.A., Kabak, L.L., Kataev, B.M., Makarov, K.V., Shilenkov, V.C., 1995. A Cheklist of the groundbeetles of Russia and Abjacent Lands (Insecta, Coleoptera, Carabidae). Pensoft publishers, Sofia Moscow.

Kunitsky, V.V., 1998. The Ice Complex and cryoplanation terraces on Bolshoy Lyakhovsky Island. In: Problems of Geocryology. Melnikov Permafrost Institute SB RAS, Yakutsk, pp. 60-72 (in Russian).

Kuzmina, S., 1987. Holocene insects and pollen record from the Chroma Bay coast (northern Yakutia). In: Proceedings of the 13th Conference of Young Scientists MSU, Geology, Moscow, MSU, BINITI 04.02.87, No. 808-B87, 23-30 (in Russian).

Kuzmina, S.A., 1989. Late Pleistocene insects from the Alazeya River (Kolyma Lowland). Byulleten' of the Moscow Society of Naturalists (MOIP), Seria Geologicheskaya, vol. 64(4), pp. 42-55 (in Russian).

Kuzmina, S.A., 2001. Quaternary Insects of the Coastal Lowlands of Yakutia. Ph.D. Thesis in Biology, Paleontological Institute, RAS, Moscow (in Russian).

Kuzmina, S.A., 2003. Recent insects of the Central Lena Delta. In: Grigoriev, M.N., et al. (Eds.), Russian German Cooperation SYSTEM LAPTEV SEA The expedition 2002, Reports on Polar Research, vol. 466. pp. 68-69.

Kuzmina, S., Bolshiyanov, D., 2002. Forest insect spectra in Late Holocene deposits of the Lena Delta terrace, north of the actual tree line. Polarforschung 70, 101-105.

Kuzmina, S.A., Kolesnikov, S.F., 2000. Insects from the Upper Pleistocene and Holocene deposits of the Medvezhyi Islands (EastSiberian Sea). Byulleten' of the Moscow Society of Naturalists (MOIP), Otd. Geologicheskiy, vol. 75(2), pp. 68-71 (in Russian).

Kuzmina, S., Kuznetsova, T., Sher, A., 1999. Paleontological research on the Bykovsky Peninsula. In: Rachold, V., Grigoriev, M.N. (Eds.), Russian German Cooperation SYSTEM LAPTEV SEA 2000. Report on Polar Research, vol. 315. pp. 179-187.

Kuzmina, S., Sher, A., Demyankov, S., 2002. Detailed reconstruction of the Laptev Shelf Land environment and climate during the last 50,000 
years-Mamontovy Khayata revisited. In: Terra Nostra. Schriften der Alfred-Wegener-Stiftung, Berlin, pp. 62-63.

Kuzmina, S.A., Wetterich, S., Meyer, H., 2003. Paleoecological and sedimentological studies of Permafrost deposits in the Central Lena Delta (Kurungnakh and Samoylov Islands). In: Grigoriev, M.N., et al. (Eds.), Russian German Cooperation SYSTEM LAPTEV SEA The expedotion 2002, Reports on Polar Research, vol. 466. pp. 71-81.

Kuznetsova, T.V., Kuzmina, S.A., Kunitsky, V.V., Schirrmeister, L., Sher, A.V., 1999. The fauna of alas sequences in the Ice Complex area: the case of Mamontovy Bysagasa northwest exposure, Bykovsky Peninsula. In: Fifth Workshop on Russian-German Cooperation: Laptev Sea System 2000. November 26-28, 1999, St.-Petersburg, Russia. Terra Nostra. Schriften der Alfred-Wegener-Stiftung, Koln, pp. $49-50$.

Lowe, J.J., Walker, M.J.C., 1997. Temperature variations in NW Europe during the last glacial-interglacial transition $\left(14-9{ }^{14} \mathrm{C}\right.$ ka BP) based upon the analysis of coleopteran assemblages - the contribution of Professor G.R. Coope. In: Ashworth, A.C., Buckland, P.C., Sadler, J.P. (Eds.), Studies in Quaternary Entomology-An Inordinate Fondness for Insects. Quaternary Proceedings 5, 165-176.

Lozhkin, A.V., 1976. Vegetation of west Beringia during the Late Pleistocene and Holocene. In: Kontrimavichus, V.L. (Ed.), Beringia in the Cenozoic, Vladivostok. pp. 72-77 (in Russian).

MacDonald, G.M., Velichko, A.A., Kremenetski, C.V., Borisova, C.K., Goleva, A.A., Andreev, A.A., Cwynar, L.C., Riding, R.T., Forman, S.L., Edvards, T.W.D., Aravena, R., Hammarlund, D., Szeicz, J., Gattaulin, V.N., 2000. Holocene treeline history and climate change across northern Eurasia. Quaternary Research 53, 302-311.

MacPhee, R.D.E., Tikhonov, A.N., Mol, D., de Marliave, Ch., van der Plicht, H., Greenwood, A., Flemming, C., Agenbroad, L., 2002. Radiocarbon chronologies and extinction dynamics of the late Quaternary mammalian megafauna of the Taimyr Peninsula, Russian Federation. Journal of Archaeological Science 29 (2), 1017-1042.

Makeyev, V.M., Arslanov, Kh.A., Baranovskaya, O.F., Kosmodamianskiy, A.V., Ponomareva, D.P., Tertychnaya, T.V., 1989. Stratigraphy, geochronology and paleogeography of Late Pleistocene and Holocene of Kotel'nyy Island. Byulleten' komissii po izucheniyu chetvertichnogo perioda 58, 58-69 (in Russian).

Makeyev, V.M., Ponomareva, D.P., Pitulko, V.V., Chernova, G.M., Solovyeva, D.V., 2003. Vegetation and climate of the New Siberian Islands for the past 15,000 years. Arctic, Antarctic, and Alpine Research 35 (1), 55-66.

Meyer, H., Dereviagin, A.Yu, Siegert, C., Hubberten, H.-W., 2002. Paleoclimate studies on Bykovsky Peninsula, North Siberia-hydrogen and oxygen isotopes in ground ice. Polarforschung 70, 37-51.

Morlan, R.E., Matthews Jr., J.V., 1983. Taphonomy and paleoecology of fossil insect assemblages of Old Crow River Locality (CRH-15), northern Yukon Territory. Geographie Physique et Quaternaire 37, $147-158$.

Nagaoka, D., Saijo, K., Fukuda, M., 1995. Sedimental environment of the Edoma in high Arctic eastern Siberia. In: Proceedings of the Third Symposium on the Joint Siberian Permafrost Studies between Japan and Russia in 1994, Tsukuba, Japan, pp. 8-13.

Nazarov, I.V., 1984. Reconstruction of Byelorussian Landscapes based on Paleoentomological Data. Nauka Press, Moscow (in Russian).

Pisaric, M.F.J., MacDonald, G.M., Velichko, A.A., Cwynar, L.C., 2001. The Lateglacial and Postglacial vegetation history of the northwestern limits of Beringia, based on pollen, stomate and tree stump evidence. Quaternary Science Reviews 20, 235-245.

Porinchu, D.F., Cwynar, L.C., 2002. Late-Quaternary history of midge communities and climate from a tundra site near the lower Lena River, Northeast Siberia. Journal of Paleolimnology 27, 59-69.

Reference Book on Climate of the USSR, 1966-1968. Issue 24 (Yakutskaya ASSR), Gidrometeoizdat, Leningrad, Part 2; Part 4 (in Russian).

Rybakova, N.O., Tshernyshova, M.B., 1979. New evidence on the Holocene flora in Yakutia. Bulletin of the Moscow Society of Naturalists (MOIP), Series Geology 54 (4), 125-131 (in Russian).
Schirrmeister, L., Siegert, C., Kunitsky, V.V., Grootes, P., Erlenkeuser, H., 2002a. Late Quaternary ice-rich permafrost sequences as an archive for the Laptev Sea environment. International Journal of Geosciences (Geologische Rundschau) 91, 154-167.

Schirrmeister, L., Siegert, C., Kuznetsova, T., Kuzmina, S., Andreev, A.A., Kienast, F., Meyer, H., Bobrov, A., 2002b. Paleoenvironmental and paleoclimatic records from permafrost deposits in the Arctic region of northern Siberia. Quaternary International 89, 97-118.

Schirrmeister, L., Kunitsky, V.V., Grosse, G., Schwamborn, G., Andreev, A.A., Meyer, H., Kuznetsova, T., Bobrov, A., Oezen, D., 2003. Late Quaternary history of the accumulation plain north of the Chekanovsky Ridge (Lena Delta, Russia) - a multidisciplinary approach. Polar Geography 27 (4), 277-319.

Semiletov, I.P., 1999. The failure of coastal frozen rock as an important factor in the biogeochemistry of the Arctic Shelf water. Doklady Earth Science 369 (8), 1140-1143 (J. Atm. Sci. 56, 286-306).

Sher, A.V., 1997. Late-Quaternary extinction of large mammals in Northern Eurasia: a new look at the Siberian contribution. In: Huntley, B., Cramer, W., Morgan, A.V., Prentice, H.C., Allen, J.R.M. (Eds.), Past and Future Rapid Environmental Changes: The Spatial and Evolutionary Responses of Terrestrial Biota. NATO ASI Series, I 47. Springer, Berlin, pp. 319-339.

Sher, A., Parmuzin, I., Bortsov, A., 2000. Ice complex on the Bykovsky Peninsula. In: Rachold, V., Grigoriev, M.N. (Eds.), Russian-German Cooperation System Laptev Sea 2000: The Expedition LENA 1999. Reports on Polar Research, Alfred-Wegener-Institute for Polar and Marine Research, Bremerhaven, vol. 354. pp. 169-182.

Sher, A., Gukov, A., Sofronov, Yu., Kuzmina, S., Sulerzhitsky, L., 2002 a. Moose and tall shrubs: new evidence on the Early Holocene climatic optimum in the Lena Delta. International Conference "Climate Drivers of the North" (Kiel, May 8-11, 2002). Terra Nostra. Schriften der Alfred-Wegener-Stiftung, Berlin, pp. 100-101.

Sher, A., Kuzmina, S., Lisitsyna, O., Parmuzin, I., Demyankov, S., 2002 b. Paleoecological and permafrost studies of Ice Complex in the Laptev Sea area (Bykovsky Peninsula). In: Grigoriev, M.N., et al. (Eds.), Russian German Cooperation SYSTEM LAPTEV SEA The expedition 2001, Reports on Polar Research, vol. 426. pp. 94-107.

Sher, A., Kuzmina, S., Kiselyov, S., Lister, A., 2003. Tundra-steppe environment in arctic Siberia and the evolution of the woolly mammoth. In: Storer, J.E. (Ed.), Third International Mammoth Conference 2003, Program and Abstracts. Yukon: Palaeontology Program, Department of Tourism and Culture. Occasional Papers in Earth Sciences, vol. 5. pp. 136-142.

Sher, A.V., Kuzmina, S.A., Kuznetsova, T.V., Sulerzhitsky, L.D., 2005. New insights into the Weichselian environment and climate of the Eastern-Siberian Artic, derived from fossil insects, plants, and mammals. Quaternary Science Reviews 24 (5-6), 533-569.

Sher, A.V., Kuzmina, S.A., Kiselyov, S.V., Korotyaev, B.A., Alfimov, A.V., Berman, D.I., 2006. QUINSIB-The Database on Quaternary Insects of North-Eastern Siberia (Preliminary version 2, 02. 06).

Sulerzhitsky, L.D., 1995. Features of the radiocarbon chronology of mammoth (Mammuthus primigenius) in Siberia and North of East Europe. In: G. Baryshnikov (Ed.), Studies of Pleistocene and Recent Mammals, Proceedings of the Zoological Institute, Russian Academy of Sciences, vol. 263. pp. 163-183 (in Russian).

Tumskoy, V.E., 2002. Thermokarst and its role in development of the Laptev Sea region during Late Pleistocene and Holocene. Ph.D. (Candidate) Thesis in Geology, MSU, Moscow (in Russian).

Vartanyan, S.L., Garutt, V.E., Sher, A.V., 1993. Holocene dwarf mammoths from Wrangel Island in the Siberian Arctic. Nature 362, $337-340$.

Velichko, A.A., Catto, N., Drenova, A.N., Klimanov, V.A., Kremenetski, K.V., Nechaev, V.P., 2002. Climate changes in East Europe and Siberia at the Late Glacial-Holocene transition. Quaternary International 91, 75-99.

Yurtsev, B.A., 1981. Relict steppe vegetation complexes of Northern Asia (Problems of reconstruction of the cryoxerotic landscapes of Beringia). Nauka, Novosibirsk (in Russian). 